\title{
A EVOLUÇÃO DO SISTEMA DAS CONSOANTES PORTUGUESAS
}

(Continuação: Do latim lusitânico ao romance galego e do galego ao galego-português).

\section{EURICO BACK}

\section{Evolução vocabular.}

O primeiro estado lingüístico mudou a fonologia do vocábulo, mudando a natureza do acento $(6.1)$ e dando preferência a vocábulos paroxítonos, como se fôsse estabelecê-los como padrão vocabular.

No segundo estado lingüístico opera-se uma evolução do padrão vocabular de características diferentes, erigindo outras marcas para o limite vocabular: altera-se o encontro de sílabas no interior do vocábulo.

Quem abriu o caminho para êste tipo de mudança, foi a fonemia de $/ \mathrm{v} /(8.1$ e 9.1). O nôvo fonema, que era muito raro entre vogais (8.1), atraiu para o seu domínio o (b) intervocálico (8.2). / v/ e /b/ estão em franca oposição apenas em início de vocábulo; nos demais ambientes não há oposição. Pois /V/ só ocorre em início de sílaba, em posição intervocálica.

$11.1 .0 / \mathrm{v} /$ passa a açambarcar o terreno de /b/ em outros ambientes: no início de silaba, quando precede semivogal ou $/ 0 /$. $0 / \mathrm{b} /$ só se mantém em início de sílaba, quando precede $/ \mathrm{m} /$, consoante, oclusiva, nasal: $\circ / \mathrm{b} /$ se mantém, quando há cerramento total da bôca ou pausa. Precede um fonema de maior abrimento bucal, ocorre $/ \mathrm{v} /$. Portanto, neste ambiente, interior do vocábulo, os dois fonemas, /b/ e / $/ \mathrm{l}$ se comportam como se fôssem alofones. A sua única oposição está em início de vocábulo, fato que talvez tenha contribuído para que no curso da história houvesse a tendência de eliminar a oposição entre os dois fonemas pela troca constante entre / $/$ e / b/ nos vocábulos.

A diafonia de (b) para (v) traz consigo uma restrição no encontro de sílabas no interior do vocábulo: /b/, labial, oclusiva, sonora não pode iniciar sílaba depois de vogal ou / $/ \mathrm{g}$. Mantém-se depois de $/ \mathrm{m} /$ - umbra "sombra". 
Exemplos:

\begin{tabular}{|c|c|c|c|c|}
\hline tenebras & "trevas" & $\ldots$ & /'tEnEboas/ & - /'tEnEvoas/... \\
\hline febrim & "febre" & . & /'fEbog/ & - /'fEvgE/ ...,arc. \\
\hline habuit & "houve" & . & /'abwe/ & - /'arwe/... \\
\hline rubeum & "ruivo" & . & /'nobyo/ & - l'govyol \\
\hline ubiam & "goiva" & $\ldots$ & /'gobya/ & - /'govya/... \\
\hline biem & "raiva" & $\ldots$ & /'gabya/ & - /'oavyal \\
\hline
\end{tabular}

A eliminação de oclusiva sonora em inicio de silaba passa a estender-se às demais oclusivas.

11.2. /d/, apical, oclusiva, sonora, em início de silaba não-inicial, desaparece, quando precedida de vogal ou de semivocóide. A defonia da apical foi possivel, porque não havia conflito entre VCV e $V V$, pela eliminaçāo quase total dos hiatos. Isto significa que pronunciar um vocábulo com /d/ entre vogais ou proferir um hiato em vez do /d/ não produzia nôvo vocábulo. São poucos os vocábulos com o grupo $/ \mathrm{d} n$ g em início de silaba, o que se explica pela fonologia histórica do latim (Niedermann, 1945, 195-6). Estes vocábulos perderam o /d/ como se comprova pelos exemplos corenta, arc. de quadraginta, coresma, arc. de quadragesima e hera de edra do latim hederam. Quadra - caira, arc. e cathedra - cadeira se explicam por serem empréstimos do latim culto, através das formas intermediárias * quagra e * categra. Cathedra, é empréstimo no latim clássico, do grego.

Se fizermos uma comparação entre a sílaba iniciada por /b/ ou $/ d /$, verificamos a analogia de tratamento:

Fonema precedente Evolução: Ambiente:

$\begin{array}{lll}\text { Vogal ou } / g / & \text { (b) }-(v) & \text { início de sílaba não-inicial } \\ \text { Vogal ou } / w / & \text { (d) }- \text { "zero" início de silaba não-inicial }\end{array}$

As oclusivas sonoras eram consoantes fracas. $O / b /$ se enfraqueceu mais, passando a $/ \mathrm{v} /$, aproveitando a casa vazia oferecida pela silaba não-inicial. $\mathrm{O} / \mathrm{d} /$ enfraquecendo-se não encontrou uma fricativa correspondente; mas encontrou uma casa vazia oferecida pelo padrão vocabular: não havia encontro de duas silabas (pelo merios em larga escala) em hiato. A apical também era uma consoante fraca e enfraqueceu mais a ponto de desaparecer.

Ocorreu mais uma restrição para o/d/ inicial de sílaba, entretanto de forma diferente: 
$\frac{\varrho}{w}$ dy : o grupo $/$ dy/, inicial de silaba e precedido de / $/$ ou $/ \mathrm{w} /$

foi substituído por $/ t^{s} /$. Não se trata de evolução fônica, mas de evolução vocabular: mudança de encontro de sílabas.

Não desapareceu o /d/ seguido de vogal, quando precedido de /Q/: cardu- para cardo; perdere para perder. Eram freqüentes os vocábulos que tinham o encontro silábico / gd/ entre vogais como /o/ entre vogais. Por esta razão se manteve o/d/, neste ambiente. Compare: cardu. "cardo" com caru- "caro".

Mas o grupo /dy/ não tinha êsse problema. 0 som mais semelhante que existia na língua era $/ \$ s /$, com o qual não estava em oposição. Eram semelhantes, porque o grupo inicia por uma apical oclusiva, e a africada também. A maior dificuldade era que em sua realização fônica o (d) era fraco e o ( $t$ ) forte. A substituição do grupo pela africada deve ter seguido o seguinte caminho: enfraquecendo-se o (d) tornou-se africado (caminho que pode ter seguido 0 (b) na passagem para $\circ(v)$ ). Como africado sonoro seria alofone de $\mid t^{\mathrm{S}} /$ e nada impedia então o ensurdecimento de (d) africado $=\left(\mathrm{d}^{\mathrm{z}}\right)$. Pelo contrário: valendo a tendência para eliminar as consoantes cclusivas, sonoras em início de sílaba, encontrou a porta aberta: ( $\mathrm{d}^{\mathrm{z}}$ ) tornou-se $\left(t^{S}\right)$, porque os dois sons não estavam em oposição, eram sons semelhantes e o surdo não contrariava o padrão vocabular como inicial de sílaba.

\section{Exemplos.}

\begin{tabular}{|c|c|c|c|}
\hline $\begin{array}{l}\text { videre } \\
\text { pedem } \\
\text { sedere } \\
\text { medicinam } \\
\text { gradum } \\
\text { hodie } \\
\text { radium } \\
\text { medium } \\
\text { videam } \\
\text { hederam } \\
\text { audire } \\
\text { laudare } \\
\text { audio } \\
\text { ardeo } \\
\text { uiridia(1) }\end{array}$ & $\begin{array}{l}\text { "ver" } \\
\text { "pé" } \\
\text { "ser" } \\
\text { "mezinha" } \\
\text { "grau" } \\
\text { "hoje" } \\
\text { "raio" } \\
\text { "meio" } \\
\text { "veja" } \\
\text { "hera" } \\
\text { "ouvir" } \\
\text { "louvar" } \\
\text { "ouço" } \\
\text { "arço", arc. } \\
\text { "verça", arc. }\end{array}$ & 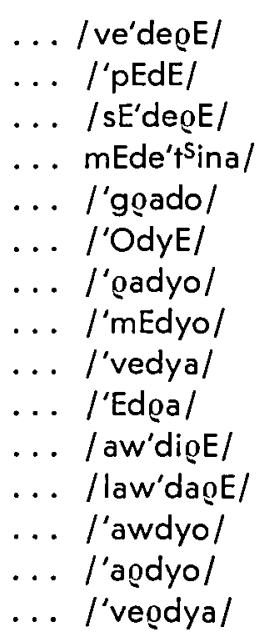 & 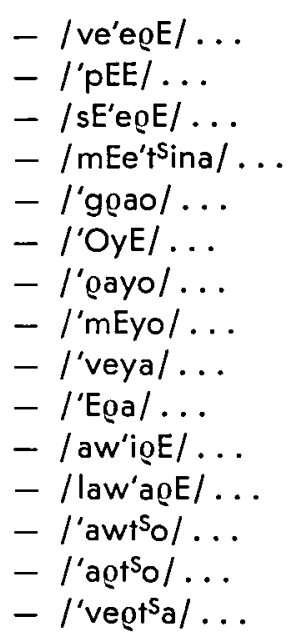 \\
\hline
\end{tabular}

(1) E preciso partir do latim uirdia, vecábulo formado sôbre virdem. Não é oriundo do latim uiridia. Prova-o a posição do acento. 


\section{$11.30 / \mathrm{g} /$ inicial de silaba.}

A lingua passa a eliminar também sílaba iniciada por $/ \mathrm{g} /$, quando precede uma vogal. Neste caso, o / g/ estava sempre entre vogais; pois a seqüência /go/, medial de vocábulo, não forma um grupo consonantal no latim lusitânico: o $(\mathrm{g})$ era implosivo e pertencia à sílaba precedente e o / $/$ / à sillaba seguinte. O latim lusitânico conservou um arcaísmo de pronúncia (do latim arcaico, enquanto no latim clássico e no latim imperial, em geral, o (g) passou a explosivo, i.e., passa a pertencer à sílaba seguinte. (Maurer, 1959, 70). "As palavras em que o grupo gr perdurou inalterado... são semieruditas ou empréstimos de cutras línguas..." (Williams, 1961, 88).

$O(g)$ sofreu diafonia para $(y)$. Tomou o mesmo caminho seguido pelo alofone no $1 .{ }^{\circ}$ estado linguístico $(q-y)$. $O(y)$ oriundo dêste alofone (g) não provocou nenhuma confusão vocabular com o $(y)$ oriundo de $(q)$, porque êste ocorria diante de vogais anteriores e aquêle diante de vogal baixa ou diante de vogais posteriores (3.2.). Também näo criou confusão vocabular com $\circ(y)$ provindo da eliminação dos hiatos (6.2), porque nestes casos o (y) era precedido de consoante e a atual diafonia coloca o (y) entre vogais. Entretanto ficou no mesmo ambiente, isto é, entre vogais, onde já estava em algumas palavras herdadas do latim (cuius, maiu-) e onde ficou pela síncope de (d), inicial de silaba e seguido de (y) (radium). Parece que nem umas nem outras eram numerosas.

Não é preciso que tenha sido gradual a passagem de (g) para (y). (g) era dorsal e oclusivo; o (y) é palatal e semivocóide. Trata-se de evolução vocabular que elimina encontro de sílaba que termina por vogal, diante de uma sílaba que inicia por dorsal oclusiva. /g/ e $/ y /$ eram ambos fonemas posteriores e dos mais semelhantes entre si, na série dos fonemas posteriores.

"Aquelas palavras em que o - $\mathrm{g}$ '- se conserva foram introduzidas na língua em época provàvelmente muito posterior, na sua maioria por via erudita..." (Nunes, 1951, 105). O mesmo vale para a dorsal oclusiva ou se mantém a teoria que $(g)$ se conserva em posição anterior ao acento vocabular. "A dissolução do -g'- em -i- parece confirmada por antigas grafias castelhanas..." (Nunes, 1951, 101.) Aliás, seria possivel a sua conservação, a síncope, a passagem para (y), já que não se trała de evolução fonêmica, mas ùnicamente de evolução vocabular. Preferimos a solução de $(g)-(y)$, pelas razões seguintes:

I. Do latim saga... “... saia é... muito antigo e não apenas em Portugal, mas em alguns dos romonces hispânicos e tanto assim 
que... pode igualmente encontrar-se em fontes arábicas (xaiiâ é 'túnica, saia de mulher'... no Códice Escurialense de 1049... Não parece... aceitável a hipótese de se tratar de galicismo, pois o fr. saie não se documenta antes do séc. XVI (Rabelais) e, ainda por cima, é voc. masc. Em 953: "Accepimus de uos... I saia..." (Machado).

II. Uma evolução mais coerente: A labial se modifica em (v); as oclusivas sonoras, no correr da história, (d), (l) e (n) sofrem síncope; a dorsal, que não tinha fricativa correspondente, foi para o semivocóide correspondente, fato que também se verifica com $(\mathrm{k})$ e $(\mathrm{g})$ implosivos (lacte - leite; integrum - inteiro, flagrare - cheirar). E não se mantém nenhuma consoante oclusiva, nestes ambientes.

III. Como não se trata de evolução fonêmica, empréstimos do latim podiam mais cedo ou mais tarde reintroduzir vocábulos com /g/ neste ambiente; empréstimos de outros dialetos hispânicos podiam trazer formas sem representante do /g/ latino; a evolução normal do português pode eliminar $\circ(y)$ e assim dar a aparência de que houve síncope do (g).

Exemplos:

\begin{tabular}{|c|c|c|c|}
\hline $\begin{array}{l}\text { sagum } \\
\text { strigam } \\
\text { legalem } \\
\text { regalem } \\
\text { ligare }\end{array}$ & $\begin{array}{l}\text { "saio" } \\
\text { "estria" } \\
\text { "leal" } \\
\text { "real" } \\
\text { "liar" }\end{array}$ & $\begin{array}{l}\ldots \text { /'sago/ } \\
\ldots \text { /es'tgiga/ } \\
\ldots \text { /le'gale/ } \\
\ldots \text { / / ge'galE/ } \\
\ldots \text { /le'gaoE/ }\end{array}$ & $\begin{array}{l}\text { - /'sayo/... } \\
\text { - /es'toiya/... } \\
\text { - /le'yalE/... } \\
\text { - /ge'yalE/... } \\
\text { - /le'yaoE/... }\end{array}$ \\
\hline
\end{tabular}

Resultado desta evolução do padrão vocabular:

Sílaba que termina em vogal, não é seguida de oclusiva sonora;

Sílaba que termina em ditongo, não é seguida de oclusiva sonora; sonora.

Sílaba que termina em $/ \varrho /$, não é seguida de labial, oclusiva,

\section{Evolução silábica.}

\subsection{Restriçāo à semiconsoante (y).}

No tipo silábico CCV, o $(y)$ é eliminado como segunda consoante em muitos grupos. Desaparece depois $(\tilde{n}),(L)$ e $\left(t^{\mathrm{S}}\right)$. "G $+\mathbf{y}$ e d $+y$ tornaram-se simples iode." (Williams, 1961, 20.)(1).

"C + iode tornou-se [tsi]. Um ou dois séculos antes, $t+$ iode

(1) O grupo (dy) foi eliminado por evolução vocabular (11.2); a seqüência (gy), se é que existiv, ccmo seria o empréstimo spongia, vocalizou o $/ \mathrm{g} /$, que era realizado por (q) e qua evoluiu para $(y)(8.3) ;$ na seqüência (yy), um icde foi eliminado. 
também tornou-se [tsi], mas êsse som modificou-se para [ts] pelo tempo em que c + iode se tornava [tsi]. Ver GVL, $\$ \S 277-8 . "$ Williams, 1961, 20.) Parece-nos que a evolução mais antiga deve ter sido de (c) para $\left(t^{S}\right)$ por pressão do sistema. O grupo (ty) não sofria pressão e ali não houve evolução fônica, mas evolução silábica que restringe os ocupantes da segunda consoante. Não parece plausivel que fôssem de época diferente a evolução de (c) diante de vogal e a evolução de (c) diante de (y). O fonema $/ t^{5} /$ só ocorria diante de vogais anteriores e foi colocado diante das demais vogais pela evolução de (cy) e de (dy) $(9.2$ e 11.2.$)$; aparentemente eram poucos vocábulos.

O grupo (ty) ocorria diante de vogais posteriores e diante de vogal baixa. A vingar a tendência de eliminar $o(y)$ como segunda consoante, o grupo (ty) só tinha dois caminhos: a pura síncope de (y). Esta mudança deveria trazer choques, porque era freqüente o (t) diante de vogal baixa e vogais posteriores. O segundo caminho era colocar primeiro a africada correspondente ao (t), isto $e, \circ\left(t^{5}\right)$ e depois eliminar a semiconsoante. A língua enveredou pelo segundo caminho: não havia conflito vocabular e são semelhantes na pronúncia a apical africada e apical seguida de iode.

"As palavras em que st mais iode se tornaram ch são empréstimos do galego: bestiam - bicha; comestionem - comichāo." Williams, 1961, 90).

Exemplos:

\begin{tabular}{|c|c|c|c|c|}
\hline $\begin{array}{l}\text { ingenium } \\
\text { araneam } \\
\text { lineam } \\
\text { teneo } \\
\text { vineam } \\
\text { mulierem } \\
\text { valeam } \\
\text { alienum } \\
\text { lanceam } \\
\text { lanceare } \\
\text { faciem } \\
\text { fiduciam } \\
\text { rationem } \\
\text { linteum } \\
\text { prefiare } \\
\text { uitium } \\
\text { linteolum } \\
\text { tristitiam }\end{array}$ & $\begin{array}{l}\text { "engenho" } \\
\text { "aranha" } \\
\text { "linha" } \\
\text { "tenho" } \\
\text { "vinha" } \\
\text { "mulher" } \\
\text { "valha" } \\
\text { "alheio" } \\
\text { "lança" } \\
\text { "lançar" } \\
\text { "face" } \\
\text { "fiúza" } \\
\text { "razäo" } \\
\text { "lenço" } \\
\text { "prezar" } \\
\text { "vêzo" } \\
\text { "lençol" } \\
\text { "tristeza" }\end{array}$ & 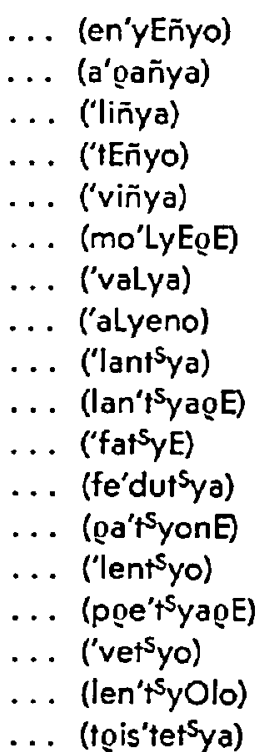 & $\begin{array}{l}- \\
- \\
- \\
- \\
- \\
- \\
- \\
- \\
- \\
- \\
- \\
- \\
- \\
- \\
- \\
-\end{array}$ & 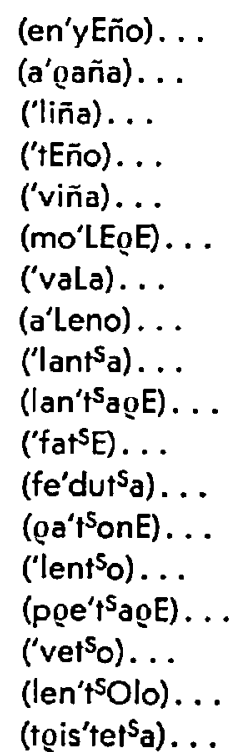 \\
\hline
\end{tabular}




\subsection{Restrição a (k) e (g) posvocálicos.}

Era na geminação que as consoantes se mantinham como posvocálicas (i.e., implosivas; já no latim vulgar houve grande restrição às consoantes posvocálicas, de sorte que das oclusivas ainda se mantinham apenas $\circ(\mathrm{k})$ e $\circ(\mathrm{g}) \mathrm{v} .7 .1$.$) . E assim mésmo apenas no$ interior do vocábulo.

No $2 .^{\circ}$ estado lingüístico se amplia a restrição para os ocupantes da consoante posvocálica. Desaparecem como implosivas da língua as consoantes $(k)$ e $(g)$. Fora da geminação, pode ser implosiva:

a) a fricativa (s);

b) as nasais $(m)$ e $(n)$;

c) a vibrante (o);

d) os semivocóides $(w)$ e ( $y$ ), aquêle no ditongo /aw/ e êste pela vocalização de (l) em sílaba intensiva (multum);

e) a lateral (l) em sílabas fracas; mas foi reintroduzido em sílabas intensivas pelos empréstimos (topônimos e antropônimos) germânicos e mais tarde árabes (cf. Williams, 1961, 99.), ou eruditos ou por evolução vocabular, devida à analogia.

As posteriores implosivas $(k)$ e ( $g$ ) são substituídas por $(y)$ : não havia, neste ambiente, oposição entre os dois fones, pois o (g) ocorria ùnicamente diante da vibrante (diante de $(\mathrm{m})$ em um empréstimo: pigmenta) e $\circ(k)$ ocorre nos demais ambientes posvocálicos. Assim não surgiu confusão entre vocábulos. Vocábulos nos quais (I) passou a $(y)$, não parecem ter sido em grande número para haver confusão possível.

\section{Exemplos.}

\begin{tabular}{|c|c|c|c|}
\hline $\begin{array}{l}\text { mataxam } \\
\text { iactare } \\
\text { lac } \\
\text { octo } \\
\text { noctem } \\
\text { luctare } \\
\text { saxum } \\
\text { sex } \\
\text { luxum } \\
\text { piscem(1) }\end{array}$ & $\begin{array}{l}\text { "madeixa" } \\
\text { "jeitar" arc. } \\
\text { "leite" } \\
\text { "oito" } \\
\text { "noite" } \\
\text { "lutar" } \\
\text { "seixo" } \\
\text { "seis" } \\
\text { "luxo" } \\
\text { "peixe" }\end{array}$ & 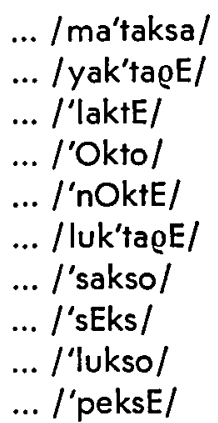 & $\begin{array}{l}\text { - /ma'taysa/... } \\
\text { - /Yyay'tagE/... } \\
\text { - /'IaytE/... } \\
\text { - /'Oyto/... } \\
\text { - /'nOytE/... } \\
\text { - /luy'tapE/... } \\
\text { - /'sayso/... } \\
\text { - /'sEys/... } \\
\text { - /'luyso/... } \\
\text { - /'peysE/... }\end{array}$ \\
\hline
\end{tabular}

(1) A seqüência (sk) foi substituido, no latim, por (ks), segundo Gonçalves Viana (apud Nunes, 1951, 132), diante de vogais anteriores. Por conseguinte, nāo podemos partir do latim clássico /"piskem/, mas do latim vulgar /'pikse/... 


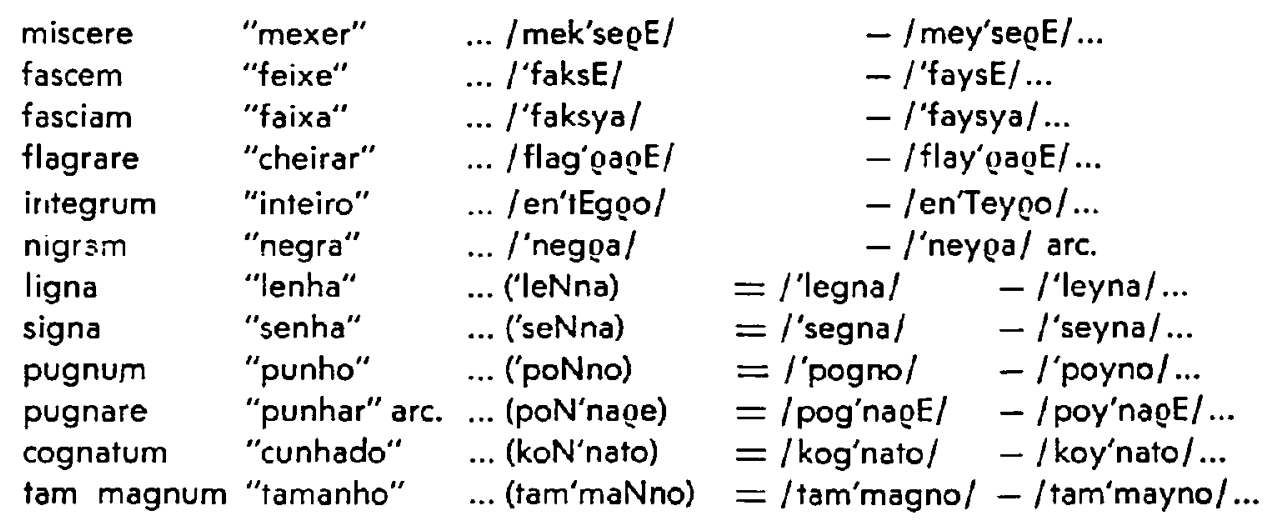

A diafonia de $(N)$ para $(y)$ é, ao mesmo tempo, a defonia irrestrita do $(N)$ : desapareceu da língua.

"Em palavras eruditas o c de ct geralmente caiu..." (Williams, 1961, 96.). "Nas palavras semi-eruditas, se seguidas de eu $\mathbf{i}$ tornaram-se c..." (Williams, 1961, 93.). "E tanto da índole da língua a vocalização do c no grupo -ct-, e ainda do g, seguido doutra consoante, quando precedidos de vogal, que se nota ainda em palavras de proveniência culta, a única diferença está em que nestas, em vez de $\mathbf{i}$, apareceu u, tais são: as arcaicas auto, autivo, auçom, carautelas, pauto, trauto, trautar, Maudalena ou Moudalena hoje Madalena ou Madanela (pop.), de actu-, activu-, actione-, caracteres, pactu-, tractu-, tractare, Magdalena." (Nunes, 1951, 123-4). "Uma espécie de fusão ou contaminação ocorreu entre eix- inicial do lat. ex- e ax- seguidos de vogal e do lat. asc $+\mathbf{i}$ " (breve) "e ens- inicial (do lat. ins-), resultando num prefixo nôvo, enx...." (Williams, 1961, 115.)

$O$ (k) implosivo, diante de /s/ mais outra consoante, já havia desaparecido no latim (Niedermann, 1945, 230.). "Seguido de uma oclusão surda... extraneum... sextum... nessa posição desapareceu em latim vulgar... (Williams, 1761, 97.)

obs. $O(k)$ implosivo entre duas consoantes foi totalmente eliminado. "É dificil determinar a época dessa modificação (Carnoy, 165-166.) Não ocorreu no latim vulgar da Gália e em certas outras regiōes (GVL, § 267)." (Williams, 1961, 87.)

Exemplos.

$\begin{array}{lll}\text { sanctum "santo" } & \ldots \text { /'sankto/ } & -/ \text { 'santo/... } \\ \text { punctum "ponto" } & \ldots \text { /'ponkto/ } & -/ \text { 'ponto/... }\end{array}$




\subsection{Restrição ao tipo silábico CCV}

Enquanto o grupo próprio com / / / sofreu apenas uma readaptação no alinhamento de sílabas no vocábulo (12.2), o grupo próprio com /1/ foi eliminado. Entre os dois grupos próprios há uma semelhança de tratamento; no primeiro grupo é a $1 .^{\circ}$ consoante que se modifica; no segundo grupo é a $1 .^{\circ}$ consoante que é eliminada. O desaparecimento da primeira consoante não se faz por simples síncope, porque /I/ entre vogais tinha grande rendimento fonêmico. O grupo tomou diversos caminhos para se transformar de CCV em CV , mas é sempre o primeiro $C$ a ser eliminado do grupo.

\section{1. caso: a 1.॰ consoante é sonora.}

Do latim foram herdados vocábulos com / bl/ e com $/ \mathrm{gl} /$.

\section{Em início de vocábulo:}

/bl/: nenhum vocábulo parece ter passado diretamente do latim ao português. bulos:

/gl/: aférese: desaparece o (g) inicial; eram poucos os vocá-

Exemplos.

\begin{tabular}{|c|c|c|c|}
\hline $\begin{array}{l}\text { globellum } \\
\text { glattire } \\
\text { glandem } \\
\text { glaream }\end{array}$ & $\begin{array}{l}\text { "novelo" } \\
\text { "latir" } \\
\text { "lande" } \\
\text { "leira" }\end{array}$ & $\begin{array}{l}\ldots \text {. glO'vEllo/ } \\
\ldots \text {. glat'tieE/ } \\
\ldots \text { /'glandE/ } \\
\ldots \text {. /'glagya/ }\end{array}$ & $\begin{array}{l}\text { - /lO'vEllo/... } \\
\text { - /lat'tieE/... } \\
\text { - /'landE/... } \\
\text { - /'la@ya/... }\end{array}$ \\
\hline
\end{tabular}

Em início de sílaba:

$$
|\mathrm{bl} /| / \mid \mathrm{l} /=(\mathrm{bl})-(\lambda . \mid) \text {. }
$$

$O$ (b) sofre assimilação total ao $/ 1 /$; entretanto, enquanto o (b) está em início de sílaba, $\circ(\lambda)$ resultante está em final da sílaba precedente. Não se deve supor que houve primeiro mudança da fronteira silábica de (.bl) para (b.l.). A tendência, há longos séculos, fôra a eliminação das consoantes implosivas e teria voltado o (b) implosivo, que já fôra eliminado? Como se trata de evolução silábica e não fônica, a substituição pode ter sido imediata, sem formas intermediárias.

"No grupo bl, o b se assimilou ao I..." (Williams, 1961, 96.) "Não há palavras em que bl se tenha tornado vr. As palavras em que se tenha tornado br são semi-eruditas ou empréstimos do espanhol..." (Williams, 1961. 88). 
Exemplos.
fabulat
"fala" .../'fabla/
- I'falla/...
tabulam
"tabuinha" ... /'tabla/
- l'talla/...

Dêste vocábulo se derivou o arc. taleira, correspondente ao latim *tabularia, que pode ter existido, derivado de tabula e com mudança vocabular para *tablaria, por analogia com tabla. Ou foi derivado de tabla: tablaria.

$/ \mathrm{gl} /$

As evoluções de que tratamos nas linhas anteriores, trouxeram uma consequiência: eliminaram a consoante /l/ como segunda consoante dum grupo em que a primeira consoante fôsse uma sonora; só restava ainda o grupo $/ \mathrm{gl} /$. Aqui o (l) foi eliminado pela substituição por (L), fone que já existia na língua, talvez fonema. A seguir foi eliminada a consoante (g) dêste grupo. Surgiu a convergência fonêmica entre /ly/ e /gl/.

\section{Exemplos.}

\begin{tabular}{|c|c|c|c|c|}
\hline $\begin{array}{l}\text { singulos } \\
\text { cingula } \\
\text { tegulam } \\
\text { coagulum } \\
\text { tragulam } \\
\text { ungulam }\end{array}$ & $\begin{array}{l}\text { "senlhos",arc. } \\
\text { "cinlha", arc. } \\
\text { "telha" } \\
\text { "coalho" } \\
\text { "tralha" } \\
\text { "unha" }\end{array}$ & $\begin{array}{l}\text {...(15'senglos) } \\
\text {..('tsingla) } \\
\text {...('tegla) } \\
. \text {.(ko'aglo) } \\
\text {...('toagla) } \\
\text {...('ongla) }\end{array}$ & $\begin{array}{l}\text { - ('senglos) } \\
\text { - ('t'singLa) } \\
\text { - ('tegLa) } \\
\text { - (ko'aglo) } \\
\text { - ('tgagLa) } \\
\text { - ('ongLa) }\end{array}$ & $\begin{array}{l}\text { - ('senlos)... } \\
- \text { ('t'sinLa)... } \\
\text { - ('tela)... } \\
\text { - (ko'alo)... } \\
\text { - ('toala)... } \\
\text { - ('onLa)... }\end{array}$ \\
\hline
\end{tabular}

Conseqüência: Estas evoluçōes não alteraram os fonemas e os alofones da língua; eliminaram não um tipo silábico, CCV, apenas impuseram-Ihe restrições na classe dos acupantes da $10^{\circ}$ consoante.

Restam ainda os grupos com (l) precedido de consoante surda, além dos grupos com (o) e $(y)$ como segunda consoante.

\section{2. caso: A $10^{\circ}$ consoante 6 surda.}

Tais grupos eram $/ \mathrm{pl} /, / \mathrm{kl} /$ e $/ \mathrm{fl} /$. O grupo $/ \mathrm{tl} /$ já havia sido eliminado $(7.3)$ e o grupo /dl/ não existia.

Como no grupo $/ \mathrm{g} /$, primeiro o (I) foi assimilado parcialmente à consoante dorsal, até (L), assim também no grupo ( $k \mid$ ) houve a miesma assimilação parcial.

Como o fone (L) já existia na língua, é claro que dentro do grupo silábico houve apenas restrição quanto à ocupante da segun. da consoante: uma evolução silábica, não confluência fônica nem fonêmica. Pois até então $O(L)$ só ocorria depois de vogais e depois de ( $\lambda$ ), não depois de outras consoantes: ('filo) "filho" e ('maXlo) "maIho". Agora surge o (L) também depois de outras consoantes. 
Nos grupos /pl/ e /fl/ se fêz a mesma restrição ao ocupante fônico da segunda consoante: (l) é substituído por (L) e o fone (l) é eliminado como segunda consoante dum grupo consonantal.

Neste momento da evolução, o grupo chegou a uma encruzilhada e se dividiu em duas direções: precedido de vogal e demais ambientes.

\section{Precedido de vogal:}

O grupo próprio em que a $1 .^{a}$ consoante é $(k),(p)$ ou (f) e em que a segunda consoante é (L), passou do tipo silábico CCV para o tipo CV, pela eliminação da 1." consoante. Neste ambiente, o grupo estava sempre entre duas vogais, isto é, entre dois fonemas de grande abrimento bucal. Aumenta a freqüência de (L) no léxico, que até então era oriundo de $/ \mid \mathrm{y} /(8.5)$ e que pela queda de $(y)$ (12.1) se tornou fonema $/ L /(14.2)$.

\section{Nos demais ambientes:}

Quando não estava precedido de vogal, ou o grupo era precedido de consoante, um fonema de maior cerramento bucal, ou estava em início de vocábulo, portanto depois do silêncio, isto é, o cerramento total da bôca. Neste caso, $O(L)$ era precedido de uma consoante surda, no grupo, ao qual se assimilou parcialmente: (L), palatal, lateral, sonora, foi substituída por (c), palatal, oclusiva, surda. (p), $(k)$ e $(f)$ eram consoantes surdas, de maior cerramento bucal do que o (L). (c) é alofone de (L), pois ocorre ùnicamente depois de ( $p$ ) $(k)$ e (f), onde o fone (L) não se manifesta.

O grupo CCV, um silabema, era então realizado por duas sílabas fônicas, com um abrimento irregular em sua ordem. Não nos parece provável uma outra solução teòricamente possível: as três consoantes $(p),(k)$ e $(f)$, foram empurradas para a sílaba precedente e, por conseguinte, o grupo foi desmanchado numa seqüência que se distribui por duas sílabas. Esta solução seria melhor para o interior do vocábulo; mas não resolve os grupos iniciais de vocábulo, porque em nenhum caso houve prótese de uma sílaba com êstes grupos. E, por isso, a segunda solução deve ser abandonada.

O fato é que o fone (c) não existia na língua até então; aparece agora num ambiente único, i.e., precedido de $(p),(k)$ ou $(f)$. Estas consoantes passaram a ser redundantes nos vocábulos, porque não havia oposição vocabular entre $(k c)$ : $(c)$; entre $(p c)$ : (c); entre $(f c)$ e (c). Por esta razão, por ser a consoante redundante e estar numa ordem irregular de abrimentos, foi eliminada a primeira consoante do grupo e o tipo silábico CCV foi reduzido a CV. O único tipo silábico CCV 
que ainda restava, era aquêle em que a segunda consoante era $/ \mathrm{Q} /$, $/ w /$ ou $|y|$.

Alguém poderia objetar que esta evolução é muito complicada; entretanto, é a evolução defendida por Mattoso Camara (Camara, $1959,295)$ e nos parece que é a única que faz justiça a todos os dados conhecidos. "Há também, entretanto, passagens menos graduais e mais rápidas, porque certos sons, por demais excepcionais no sistema, logo se eliminam ou adaptam a tipos mais consentâneos com o conjunto geral. Nem é para excluir, a rigor, a possibilidade da passagem imediata de um fonema a outro." (Camara, 1959, 271).

Quem sabe alguém poderia pensar em duas outras soluçōes:

1. ${ }^{\circ)}$ Houve vocalização de (l) para (y), como planum - piano. Surgem três dificuldades: a) não houve no português vocalização de consoante explosiva; b) não se explica o (L), que surgiu quando o grupo era intervocálico; $c)$ em territórios vizinhos da Península lbérica, até o grupo inicial passou a (L), espanhol: plorare - Ilorar; clavem - llave (Camara, 1959, 295); e é melhor uma solução semelhante a dialetos vizinhos do que ao italiano, geogràficamente distante.

$\left.2 .^{\circ}\right)$ A vocalização da primeira consoante, primeiro do (k), depois de $(p)$ e (f). Também neste caso há barreiras intransponiveis: a) a passagem do (y) para a sílaba precedente; mas não seria de todo impossivel, porque também se deu com o (b) em fallo de fabulo "falo"; b) a transposição do (y) para a sílaba seguinte e o resultado seria (ly): parece que não acorreu nenhuma metátese do português para a silaba seguinte, ainda mais para uma sílaba fraca; c) como é que (kl) inicial pode dar (yl)?

Exemplos.

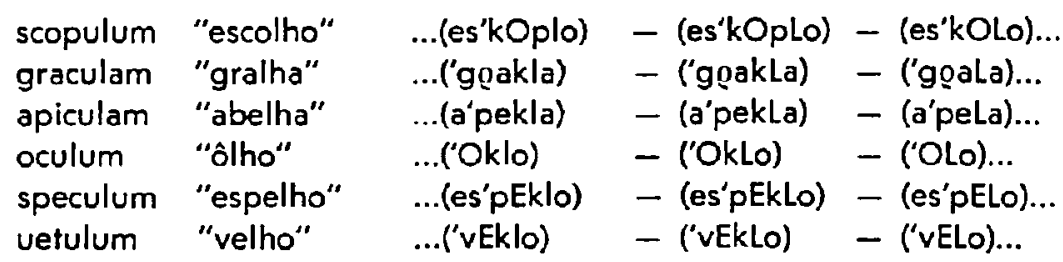

Não encontramos exemplos para /fl/ intervocálico. Masculum "macho"; sarculum "sacho"; implemus "enchemos"; amplum "ancho"; afflare "achar":

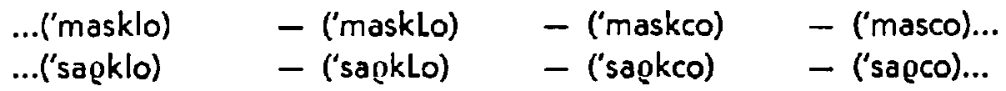


...(em'plemos) - (em'plemos) - - (em'pcemos) - (em'cemos)...

...('amplo) - - - ('amplo) - ('ampco) - ('amco)...

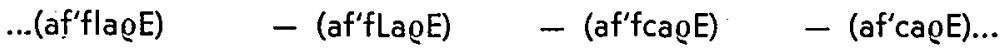

Clamare "chamar"; clauem "chave"; plantare "chantar"; plenum "cheio", plorare "chorar"; flagrare 'cheirar"; Flauiis "Chaves":

\begin{tabular}{|c|c|c|c|}
\hline ...(kla'magE') & - (KLa'magE) & $-($ kca'magE $)$ & (ca'ma $\mathrm{E}$ ) \\
\hline ...('klave) & - ('kLavE) & $-($ 'kcavE) & $-($ 'cave)... \\
\hline ...(plan & - ('plan'ta E E) & $-($ pca & $\left.\gamma^{\prime} \operatorname{tag} E\right) . .$. \\
\hline ...('pl & $-(p L \epsilon$ & $-(n$ & \\
\hline ...(plo' $Q a \varrho E)$ & - (pLo'gagE) & $-($ pco' $\varrho a \varrho E)$ & $-\left(c^{\prime} \varrho a \varrho E\right) .$. \\
\hline ...(flag'ga & - (flag' & - (fcag' $\varrho a \varrho E)$ & $-\left(c^{\prime} g^{\prime} \varrho a \varrho E\right)$. \\
\hline ...('flaves) & - ('flaves) & - ('fcaves) & - ('caves)... \\
\hline
\end{tabular}

Estes grupos foram restaurados em português por empréstimos eruditos. Com certa facilidade, porque o tipo silábico CCV não tinha sido eliminado. Aquêles vocábulos que, nestes grupos, têm o (l) substituído pela vibrante, entraram por via erudita (Nunes, 1951, 120) ou são empréstimos do moçárabe, dialeto em que $(\mathrm{kl}-)$, (pl-), (fl-) passaram a (kr-), (pr-), (fr-) (Guérios, 1956, 149). "Não estará aí, num antagonismo entre o Norte e o Sul, a explicação de muitas daquelas divergências?" (Silva Neto, 1956, 106). Compare-se flor, chor e fror "flor".

Mas o moçárabe não pode explicar vocábulos como segral de saeculare-, jogral de ioculare-, igreja de ecclesia, segre de saeculu-, porque (k) não se sonorizou neste dialeto (Guérios, 1956, 148).

\section{Evoluções fônicas.}

\subsection{Transfonia de (L) para (c).}

O fone (L), precedido de consoante surda, sofreu transfonia: de frontal, lateral, sonoro passou a frontal, oclusivo, surdo. A evolução deve ter sido gradual, substituindo-se primeiro o traço fônico de sonoro por surdo; depois o de lateral por oclusivo. Esta transfonia se fêz no meio de uma evolução silábica e já foi estudada no item 12.3.

\subsection{Transfonia de (s) para (x).}

O fone (s), apical, fricativo, surdo, quando seguido de (y) passou a $(x)$; frontal, fricativo, surdo (Grandgent, 1952, 173). Trata-se de transfonia: assimilação parcial ao $(y)$. 
Exemplos.

$\begin{array}{lllll}\text { basium } & \text { "beijo" } & \text {..('basyo) } & - \text { ('baxyo) } & =/ \text { 'basyo/... } \\ \text { caseum } & \text { "queijo" } & \text {...('casyo) } & - \text { ('kaxyo) } & =/ \text { 'kasyo } / . . . \\ \text { fasciam } & \text { "faixa" } & \text {...('faksya) } & - \text { ('fakxya) } & =/ \text { 'faksya } / . .\end{array}$

O mesmo fenômeno ocorreu no interior do vocábulo, quando o (s) era precedido de (y). E bem provável que a palatalização de (s) diante de $(y)$ tenha sido mais antiga do que depois de $(y)$, porque a proximidade de $(y)$ a um ( $\mathrm{s}$ ) na seqüência / sy/ era mais antiga: já existia no segundo estado lingüístico.

A palatalização não ocorre com o (s) final: sex - seis.

Exemplos.

$\begin{array}{llll}\text { mataxam } & \text { "madeixa" } & \ldots \text { (ma'taysa) } & -(\text { ma'tayxa)... } \\ \text { luxum } & \text { "luxo" } & \ldots \text { ('luyso) } & -(\text { 'luyxo)... } \\ \text { saxum } & \text { "seixo" } & \ldots \text { ('sayso) } & -(\text { 'sayxo)... } \\ \text { piscem } & \text { "peixe" } & \ldots \text { ("peysE) } & -(\text { 'peyxE)... } \\ \text { miscere } & \text { "mexer" } & \ldots \text { (mey'seoE) } & -(\text { mey'xeeE)... } \\ \text { fascem } & \text { "faixa" } & \ldots \text { ('faysE) } & -(\text { 'fayxE)... }\end{array}$

O Dicionário Etimológico de Machado documenta ameixenedo do ano 922 .

\section{Evoluçōes fonêmicas.}

\subsection{A fonemia de $/ \bar{n} /$.}

Pela sincope de $(y)$ depois de $(\bar{n})$, encontram-se nos mesmos ambientes, entre vogais, os fones $(\tilde{n})$ e $(n)_{i}$ assim o primeiro conquista a sua independência: tinha sido alofone de $/ n /$ e agora sofre fonemia $/ \bar{n} /$ com os traços distintivos de posterior e nasal. $/ n /$ sofre transfonemia, porque muda o seu traço distintivo de não-labial para apical. Comprovam-se como fonemas distintos pelos ambientes análogos em: pinum "pinho" /"pino/ : pineam "pinha" /'piña/ e teneo "tenho" /'tEño/.

\subsection{A fonemia de $/ L /$.}

Pelas mesmas razões do $/ \bar{n} /$, ocorre a fonemia de $/ L /$, com os traços distintivos de posterior, lateral. /1/ sofre automàticamente transfonemia por adquirir o traço distintivo de apical; pois até então possuía um único traço distintivo, o lateral. Os dois fones se comprovam como fonemas distintos pelo par mínimo filum "fio" / filo/ : filium "filho" /'filo/. 


\subsection{A fonemia de $/ t^{x} /$}

A evolução silábica (12.3), que reduziu o grupo silábico CCV para CV, colocou o fone (c) em início de sílaba. No mesmo ambiente também se encontrava $0 / \mathrm{L} /$. Enquanto não caiu a primeira consoante do grupo, (c) era alofone de /L/, porque (c) só ocorria depois de consoantes, mas nunca depois de $/ 1 /$, e $(L)$ ocorria depois de vogais e depois de $/ 1 /$.

Pela queda da primeira consoante, tornam-se fonemas diferenles, como se comprova pelos ambientes análogos, porque ambos ocorrem depois de consoantes impleo "encho" /'emco/ : ungulam "unha" /"onla/ e singulos "senlhos", arc. /'senLos/.

/c/ também é fonema diferente do / $/$ / : prova-o o par mínimo cantare "cantar" / kan'ta@E/ : plantare "plantar" / can'ta@E/.

O par mínimo tantam "tanta" /'tanta/ : plantat "chanta" /'canta/ prova que /c/ e / $t /$ também eram fonemas diferentes.

Resultado: A evolução silábica causou a fonemia de $/ \mathrm{c} /$. nôvo fonema não suportou a pressão dos seus vizinhos da série, por serem quatro, como já acontecera no $1 .^{\circ}$ estado para o $2 .^{\circ}$ (9.2). Como tinha à sua frente uma casa vazia, veio a ocupá-la por transfonemia de $/ \mathrm{c} /$ para $/ \mathrm{t}^{\mathrm{x}} /$, com os traços distintivos de posterior, africado. Não pôde tornar-se apical, porque esta casa estava ocupada pelo $/ t^{5} /$, que sofreu transfonemia por adquirir o traço distintivo de apical. Assim, o aparecimento de $/ t^{x} /$ integrou a africada $/ t^{s} /$ em série de duas casas.

Enquanto, na época anterior, o fonema / $/$ podia passar teòricamente a qualquer africada, o atual fonema $/ c /$ só encontrou uma casa vazia, próxima.

O par mínimo cenam "ceia" /'†Sena/ : plenam "cheia" / ${ }^{\dagger}{ }^{x}$ ena/ prova que $/ t^{s} /$ e $/ t^{x} /$ eram fonemas diferentes. Contudo não havia oposição entre os fones $(x)$ e $\left(t^{x}\right)$ : é a simetria que mantém $O(x)$ como alofone de $/ \mathrm{s} /$. Não se trata de sequiência de dois fonemas, $\left|t^{x}\right|$, porque os seus elementos não ocorrem isolados no mesmo ambiente.

\section{Exemplos da evolução fonêmica.}

\begin{tabular}{|c|c|c|c|}
\hline $\begin{array}{l}\text { ingenium } \\
\text { teneo }\end{array}$ & $\begin{array}{l}\text { "engenho" } \\
\text { "tenho" }\end{array}$ & $\begin{array}{l}\text { (en'yeñyo) } \\
\text { (en'yeño) } \\
\text { ('tEñyo) } \\
\text { ('tEño) }\end{array}$ & $\begin{array}{l}=/ \text { en'yenyol } \\
=/ \text { en'yeño/... } \\
=/ \text { 'tEnyo } / \\
=/ \text { 'tEño } / . . .\end{array}$ \\
\hline
\end{tabular}




\begin{tabular}{|c|c|c|c|}
\hline araneam & "aranha" & (a'ọanya) & $=$ /a'ganya/ \\
\hline mulierem & "mulher" & $\begin{array}{l}\text { (a'gaña) } \\
\text { (mo'LyEgE) } \\
\text { (mo'LEgE) }\end{array}$ & $\begin{array}{l}=/ a^{\prime} \text { gaña } / . . . \\
=/ \mathrm{mo} l y E \varrho E / \\
=/ \mathrm{mo} L E g E / . . .\end{array}$ \\
\hline valeam & "valha" & $\begin{array}{l}\text { ('valya) } \\
\text { ('vaLa) }\end{array}$ & $\begin{array}{l}=\text { I'valyal } \\
=\text { I'vaLa/... }\end{array}$ \\
\hline alienum & "alheio" & $\begin{array}{l}\text { (a'Lyeno) } \\
\text { (a'Leno) }\end{array}$ & $\begin{array}{l}=/ \text { a'lyeno/ } \\
=/ \text { a'Leno } / . . .\end{array}$ \\
\hline plantare & "chantar" & 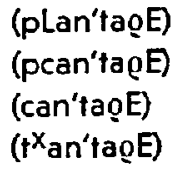 & 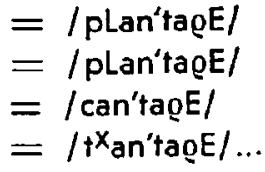 \\
\hline clamare & "chamar" & $\begin{array}{l}\text { (kLa'mapE) } \\
\text { (kca'maoE) } \\
\left(c^{\prime} \text { maoE) }\right. \\
\left(\dagger^{x} a^{\prime} \text { magE }\right)\end{array}$ & 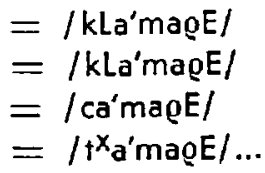 \\
\hline flammam & "chama" & $\begin{array}{l}\text { ('flamma) } \\
\text { ('fcamma) } \\
\text { ('camma) } \\
\text { ('†xamma) }\end{array}$ & $\begin{array}{l}=/ \text { 'flamma/ } \\
=/ \text { 'flamma/ } \\
=/ \text { 'camma/ } \\
=/ \text { tramma }^{x} \text {... }\end{array}$ \\
\hline marculatum & "machado" & 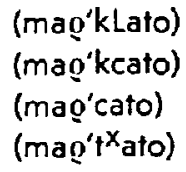 & $\begin{array}{l}=/ \text { mag'kLato } / \\
=/ \text { mag'kLato } / \\
=/ \text { mag'cato } / \\
=/ \text { mag'txato } / .\end{array}$ \\
\hline implet & "enche" & $\begin{array}{l}\text { ('em'pLE) } \\
\text { ('em'pcE) } \\
\text { ('emcE) } \\
\text { ('emt'E) }\end{array}$ & $\begin{array}{l}=/ \text { 'empLE/ } \\
=/ \text { 'empLE/ } \\
=/ \text { 'emeE/ } \\
=/ \text { 'emt } E / . . .\end{array}$ \\
\hline afflat & "acha" & $\begin{array}{l}\text { ('affla) } \\
\text { ('affca) } \\
\text { ('afca) } \\
\left(\text { 'aff } x_{a}\right)\end{array}$ & $\begin{array}{l}=/ \text { 'affla/ } \\
=/ \text { affla/ } \\
=/ \text { afcal } \\
=/ \text { 'aft } \times a / \ldots\end{array}$ \\
\hline astulam & "acha" & $\begin{array}{l}\text { ('askla) } \\
\text { ('askca) } \\
\text { ('asca) } \\
\text { ('ast'a) }\end{array}$ & $\begin{array}{l}=\text { /'askLa/ } \\
=\text { /'askLa/ } \\
=/ \text { asca } / \\
=/ \text { ast'xa/... }\end{array}$ \\
\hline tegulam & & $\begin{array}{l}\text { ('tegLa) } \\
\text { ('teLa) }\end{array}$ & $\begin{array}{l}=/ \text { 'tegla/ } \\
=\mid \text { tela } / . . .\end{array}$ \\
\hline coagulum & "coalho" & $\begin{array}{l}\text { (ko'aglo) } \\
\text { (ko'aglo) } \\
\text { (ko'aLo) }\end{array}$ & $\begin{array}{l}=\mid \text { ko'aglo } / \\
=/ \text { ko'agLo } / \\
=/ \text { ko'aLo } / . . .\end{array}$ \\
\hline
\end{tabular}




\section{Os fonemas do romance galego.}

As evoluções do segundo estado linguístico, o latim lusitânico, nos levam a um nôvo sistema, a uma nova língua, que denominamos romance galego. Estamos no terceiro estado lingüístico. O latim lusitânico já se havia cindido em dois ramos: o dialeto moçárabe, o dialeto do Sul, e o dialeto do Norte, o romance galego. São duas línguas diferentes, porque têm um sistema diferente. A mudança se operou no sistema de consoantes. (Não se alterou o sistema de vogais, continua o mesmo diagrama do latim lusitânico). Veremos as consoantes.

\subsection{O sistema das consoantes:}

o diagramema.

$\begin{array}{ll}\begin{array}{l}\text { oclusivas } \\ \text { africadas }\end{array} & \begin{array}{l}\text { surdas } \\ \text { sonoras }\end{array} \\ \text { fricativas } & \begin{array}{l}\text { surda } \\ \text { sonora }\end{array} \\ \text { nasais } & \\ \text { laterais } & \\ \text { vibrante } & \\ \text { semivocóides } & \end{array}$

\begin{tabular}{|c|c|c|}
\hline labiais & apicais & posteriores \\
\hline$/ \mathrm{p}$ & $t$ & k \\
\hline$b$ & $d$ & g \\
\hline & $t^{5}$ & $t^{x}$ \\
\hline$f$ & \multirow{2}{*}{$\mathbf{s}$} & \\
\hline$v$ & & \\
\hline$m$ & $n$ & $\tilde{\mathbf{n}}$ \\
\hline & 1 & $\bar{L}$ \\
\hline \multicolumn{3}{|c|}{$\varrho$} \\
\hline$w$ & & \\
\hline
\end{tabular}

\subsection{A norma:}

- diagrama das consoantes.

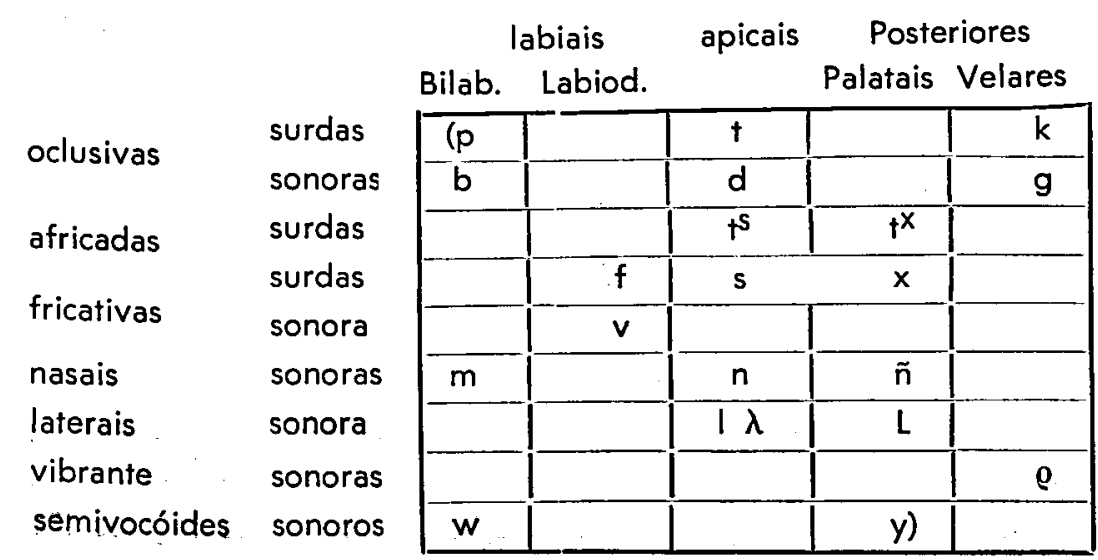


/s/ tinha dois alofones:

(x) diante e depois de $|y|$

(s) nos demais ambientes.

11/ tinha dois alofones:

(A) depois de vogal;

(1) nos demais ambientes.

\section{Exolução vocabular.}

17.1 Pela evolução vocabular que se processou no latim lusitânico (11.) e pela evolução silábica do mesmo estado lingüístico (12.3), nenhuma consoante oclusiva sonora se encontrava mais em início de silaba interior, precedida de vogal. Portanto, neste ambiente, não havia oposição entre as oclusivas surdas e as sonoras correspondentes. Em conseqüência, neste ambiente as surdas podiam ocupar a posição das sonoras e efetivamente ocuparam, sem que se criasse nenhuma confusão vocabular, nem fonêmica. Alterou-se o encontro de sílabas no interior do vocábulo: em vez de aparecer, depois de vogal, uma consoante surda passa a estar no mesmo vocábulo a sonora correspondente.

Entre as consoantes africadas, não havia, em ambiente algum, oposição entre sonoras e surdas. Entre as fricativas, havia oposição entre labial sonora e labial surda, mas tal oposição não existia na ordem apical (melhor nāo-labial). A distribuição do fonema /ff/, neste ambiente, era de frequiencia muito reduzida: ocorria em empréstimos e em antigos "compostos" do latim, como aurificem, pontificem, conficere, etc. (Niedermann, 1945, 125-7). Porém muitos dèste vocábulos não se conservaram no latim lusitânico. De sorte, a oposição entre $/ \mathrm{v} / \mathrm{e} / \mathrm{f} /$, neste ambiente, era pràticamente inexistente.

Precedida de vagal, a consoante surda em inicio interno de silaba fo: substituída pela sonora correspondente:

$$
\begin{aligned}
& (p)-(b) ; \\
& (t)-(d) ; \\
& (k)-(g) \\
& \left(t^{5}\right)-\left(d^{2}\right) \\
& (f)-(v) \\
& (s)-(z) \\
& (x)-(i)
\end{aligned}
$$

O fone $\left(t^{x}\right)$ não ocorria neste ambiente e, portanto, manteve-se em todos os ambientes. Mas o fone ( $s$ ) também se sonorizou depois de $(w)$. A tendência para a sonorização foi em certas regiões tão 
forte e, provàvelmente, tão antiga no latim imperial que também atingiu o (k) inicial; e algumas destas formas dialetais passaram ao português: całtu - gato; camella - gamela; crałe - grade; creła greda; quirilare - gritar.

\section{Exemplos.}

\begin{tabular}{|c|c|c|c|c|}
\hline apiculam & "abelha" & .../a'pela / & - /a'bela/... & \\
\hline saporem & "sabor" & .../sa'pogE/ & $-/$ sa'bogE/... & \\
\hline اllam & "cebola" & .../ts's'polla/ & $-1 t^{s} e^{\prime} b o l l a / . .$. & \\
\hline pum & "lôbo" & .../'lopo/ & - /'lobo/. & \\
\hline pram & "cabra" & .../'kapga/ & - /'kaboa/... & \\
\hline porem & "lebre" & .../'IEp@E/ & $-/ \mid E b g E / \ldots$ & \\
\hline נit & "soube" & .../'sapwe/ & - /'sabwe/... & \\
\hline io & "caibo" & .../'kapyo/ & - /'kabyo/... & \\
\hline itum & "mudo" & .../'muto/ & - /'mudo/. & \\
\hline um & "prado" & .../'pgato/ & - /'poado/... & \\
\hline netum & "mêdo" & .../'mEto/ & $-/$ mEdo/... & \\
\hline rotam & "roda" & .../'eOtal & - /'@Oda/... & \\
\hline natrem & "mãe" & .../'mateE/ & $-/ \operatorname{mad} \mathrm{E} / \ldots$ & \\
\hline atronem & "ladrão" & .../la'tgonE/ & - /la'doonE/... & \\
\hline pacare & "pagar" & .../pa'kaoE/ & - /pa'gaeE/... & \\
\hline plicare & "chegar" & $\ldots / t^{x} e^{\prime} k a \varrho E /$ & $-I^{\prime} x^{x} e^{\prime} \operatorname{gag} E / \ldots$ & \\
\hline lacum & "lago" & .../'lako/ & $-/$ lago/. & \\
\hline dico & "digo" & .../'diko/ & - /'digo/. & \\
\hline lucrum & "lôgro" & .../'lok@o/ & $-/$ logeo/... & \\
\hline sacratum & "sagrado" & .../sa'kgato/ & - /sa'g@ado/... & \\
\hline profectum & "proveito" & .../p@o'fEyto/ & - /pgo'vEyto/... & \\
\hline Stephanum & "Estêvão" & .../es'tEfano/ & - /es'tEvano/... & \\
\hline aurificem & "ourives" & ...(aw'Qifet $\left.{ }^{S} E\right)$ & - (aw'gived $d^{\mathrm{Z} E}$ ).. & $=/$ aw' givet $^{\mathrm{S} E} \mathrm{E} / \ldots$ \\
\hline dicere & "dizer" & $\ldots\left(d i^{\prime}+{ }^{s} e \varrho E\right)$ & $-\left(d^{\prime}{ }^{\prime} d^{\prime} e \varrho E\right) \ldots$ & $=/ \mathrm{di}^{\prime}{ }^{\mathrm{s}} \mathrm{e} \mathrm{RE} / \ldots$ \\
\hline vaciuum & "vazio" & $\ldots\left(v a^{\prime}+s_{j o}\right)$ & $-\left(v^{\prime} d^{\prime} z_{i o}\right) \ldots$ & $=/ v^{\prime} t^{s i o} / \ldots$ \\
\hline fiduciam & "fiúza" & $\ldots\left(f e^{\prime} u t^{s} a\right)$ & $-\left(f e^{\prime} u d^{Z} a\right) \ldots$ & $=/ \mathrm{fe}^{\prime} u t^{\mathrm{s}} \mathrm{a} / \ldots$ \\
\hline rationem & "razão" & $\ldots\left(\rho a^{\prime} t^{S} \circ \cap E\right)$ & $-\left(\varrho a^{\prime} d^{2} o n E\right) \ldots$ & $=/ \varrho a^{\prime} t^{S} \circ n E / \ldots$ \\
\hline luces & "luzes" & ...('lutses) & - ('ludzes)... & $=/$ lutses $/ \ldots$ \\
\hline vices & "vêzes" & ...('vetses) & - ('vedzes)... & $=/$ vet $^{\mathrm{s} e s} / \ldots$ \\
\hline mensam & "mesa" & ...('mesa) & - ('meza)... & $=/$ 'mesa $/ \ldots$ \\
\hline rosam & "rosa' & ...('@osa) & $-\left({ }^{\prime}\right.$ goza $) \ldots$ & $=/$ gosa $/ \ldots$ \\
\hline causam & "coisa" & ...('kawsa) & - ('kawza)... & $=/$ kawsa $/ \ldots$ \\
\hline pausare & "pousar" & ...(paw'sagE) & - (paw'za@E) & $=/$ paw'saQE/... \\
\hline basium & "beijo" & ...('baxyo) & - ('bajyo) & $=/$ 'basyo $/ \ldots$ \\
\hline caseum & "queijo" & ...('kaxyo) & - ('kaiyo) & $=/$ 'kasyo $/ \ldots$ \\
\hline
\end{tabular}




\subsection{Restrição ao (y) semivogal.}

A semivogal $(y)$, final de silaba e diante de (ñ) sofre sincope.

Exemplos.

$\begin{array}{llll}\text { ligna } & \text { "lenha" } & \text {.../'leyña/ } & -/ \text { 'leña/. } \\ \text { signa } & \text { "senha" } & \text {../'seyña/ } & -/ \text { 'señal. } \\ \text { pugnum } & \text { "punho" } & \text {.../'poyño/ } & -/ \text { 'poño/... } \\ \text { cognatum } & \text { "cunhado" } & \text {../ko'yñado/ } & -/ \text { ko'ñado/... } \\ \text { tammagnum } & \text { "famanho" } & \text {.../tam'mayñol } & -/ \text { tam'maño/... } \\ \text { pugnare } & \text { "punhar", arc. } & \text {.../poy'ñagE/ } & - \text { /po'ñagE/... }\end{array}$

Distribuição das consoantes em início interno de silaba, depois de vogal.

Antes da sonorização:

\begin{tabular}{|c|c|c|c|c|c|c|}
\hline \multirow{3}{*}{ Oelusivas } & \multirow[b]{2}{*}{ surdas } & \multicolumn{2}{|c|}{ bilabiais labiodentais } & \multirow{2}{*}{$\begin{array}{c}\text { apicais } \\
t\end{array}$} & palatais & \multirow{2}{*}{$\frac{\text { dorsais }}{k}$} \\
\hline & & $1 p$ & & & & \\
\hline & sonaras & - & & - & & - \\
\hline \multirow{2}{*}{ Africadas } & surdas & - & & $t^{s}$ & - & \\
\hline & sonoras & & & & & . \\
\hline \multirow{2}{*}{ Fricativas } & surdas & & $f$ & $\mathbf{s}$ & $x$ & \\
\hline & sonoras & & v) & & & \\
\hline
\end{tabular}

Depois da sonorização:

\begin{tabular}{|c|c|c|c|c|c|c|}
\hline \multirow{3}{*}{ Oclusivas } & \multirow[b]{2}{*}{ surdas } & \multicolumn{2}{|c|}{ bilabiais labiodentais } & apicais & palatais & dorsais \\
\hline & & - & & $y$ & & - \\
\hline & sonoras & (b & & d & & $\mathrm{g}$ \\
\hline & surdas & & & - & - & \\
\hline Africadas & sonoras & & & $d^{z}$ & & \\
\hline & surdas & & - & - & - & \\
\hline rricarivas & sonoras & & $v$ & $z$ & i) & \\
\hline
\end{tabular}

\subsection{Restrição ao (m) implosivo.}

O (m) implosivo foi substituído pela apical, nasal diante de nasal de outra ordem. Não se muda o padrão silábico, que continua $V C$, mas as ocupantes do $C$ perdem uma possibilidade, $O(\mathrm{~m})$ diante de encontro silábico que tenha a sílaba seguinte iniciada por nasal. Trafa-se de evolução vocabular porque há uma restrição no encontro silábico no interior do vocábulo. 
Exemplos.

$\begin{array}{llll}\text { dominum } & \text { "dono" } & \text {.../'dOmno/ } & -/ \text { 'dOnno/... } \\ \text { somnium } & \text { "sonho" } & \text {../'sOmño/ } & -/ \text { 'sOnño/... } \\ \text { somnum } & \text { "sono" } & \text {.../'sOmno/ } & -/ \text { 'sOnno/... } \\ \text { damnum } & \text { "dano" } & \text {.../'damno/ } & -/ \text { 'danno/... }\end{array}$

17.4. Restrição às consoantes implosivas diante de africadas.

No encontro de duas sílabas, no interior do vocábulo, em que a segunda sílaba inicie por africada e a precedente termine por consoante, há uma restrição na ocorrência desta. É que muitas consoantes ressurgiram nesta posição, oriundas de antigas geminadas (12.3): é o caso de $(p),(t),(k)$ e (f).

Essas quatro consoantes são eliminadas nessa posição, nesse encontro silábico diante de africada; o mesmo fenômeno ainda ocorreu com (s) e (@) diante da posterior africada. Conservam-se as nasais, a lateral e os semivocóides, além de (s), e ( $\mathrm{g})$ diante de $\left(t^{5}\right)$.

Exemplos.

\begin{tabular}{|c|c|c|c|}
\hline $\begin{array}{l}\text { braccium } \\
\text { applico } \\
\text { afflare } \\
\text { captiare } \\
\text { sarculum } \\
\text { mascuium }\end{array}$ & $\begin{array}{l}\text { "braço" } \\
\text { "achego" } \\
\text { "achar" } \\
\text { "caçar" } \\
\text { "sacho" } \\
\text { "macho" }\end{array}$ & 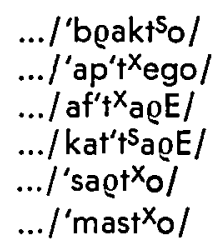 & 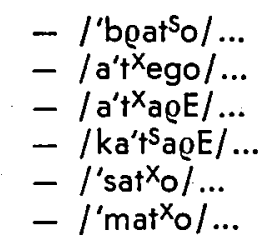 \\
\hline
\end{tabular}

\subsection{Restrição às consoantes geminadas.}

As consoantes geminadas foram interpretadas como seqüência de dois fonemas iguais, realizando-se o primeiro como alofone implosivo; o segundo, como alofone explosivo. Caía, portanto, a fronteira silábica entre os dois fonemas. Fonèticamente, porém, se produzem por uma única articulação e se distinguem por sua qualidade de longas em confronto com as simples, breves. "Latin also had phonetically long consonants, but these are better analyzed, largely for morphemic reasons, as geminate clusters." (Hill, 1958, 442).

Depois que as consoantes surdas sofreram sonorização em início interno de sílaba, desde que precedidas por vogal (17.1), não havia mais oposição entre os dois encontros silábicos seguintes:

$1 .^{\circ}$ tipo: $1 .^{a}$ sílaba: Vogal e consoante surda; $2 .^{\circ}$ sílaba: consoante surda;

2. tipo: 1.9 sílaba: Vogal; 2.9 sílaba: consoante surda.

Não havia oposição, porque o segundo tipo de encontro silábico já não mais existia na língua. Por conseguinte, no $10^{\circ}$ tipo de en- 
contro silábico a consoante surda podia ser eliminada sem que surgisse conflito vocabular. Esta eliminação satisfaz ainda a antiga tendência de eliminar as consoantes implosivas e restabelece a oposição entre consoantes surdas e sonoras também no início interno de sílabo.

As geminadas surdas, as oclusivas e as fricativas, tomaram o lugar das surdas, que já tinham evoluído. As geminadas sonoras correspondentes (bb), (dd) e (gg) tomaram o mesmo caminho da simplificação. Eram muito raras no latim (Niedermann, 1945, 160).

Exempios.

\begin{tabular}{|c|c|c|c|}
\hline $\begin{array}{l}\text { stuppam } \\
\text { cippum } \\
\text { guttam } \\
\text { mittere } \\
\text { siccum } \\
\text { peccatum } \\
\text { offendo } \\
\text { ipse } \\
\text { ossum } \\
\text { persicum } \\
\text { ruptum } \\
\text { personam } \\
\text { litteram } \\
\text { approbare } \\
\text { adducere } \\
\text { abbatem } \\
\text { sabbatum }\end{array}$ & $\begin{array}{l}\text { "estôpa" } \\
\text { "cepo" } \\
\text { "gôta" } \\
\text { "meter" } \\
\text { "sêco" } \\
\text { "pecado" } \\
\text { "ofendo" } \\
\text { "êsse" } \\
\text { "osso" } \\
\text { "pêssego" } \\
\text { "rôto" } \\
\text { "pessoa" } \\
\text { "lêtra" } \\
\text { "aprovar" } \\
\text { "aduzir" } \\
\text { "abade" } \\
\text { "sábado" }\end{array}$ & 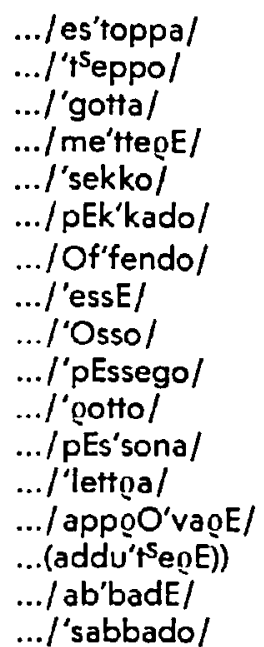 & $\begin{array}{l}\text {-/es'topa/... } \\
\text {-/'s'sepo/... } \\
\text {-/'gota/. } \\
\text {-/me'tegE/... } \\
\text {-/'seko/. } \\
\text {-/pE'kado/... } \\
\text {-/O'fendo/... } \\
\text {-/'esE/... } \\
\text {-/'Oso/... } \\
\text {-/'pEsego/... } \\
\text {-/'goto/... } \\
\text {-/pE'soa/... } \\
\text {-/'letga/... } \\
\text {-/apgo'vapE/... } \\
\text { - (adu'segE)... } \\
\text {-/a'badE/... } \\
\text {-/'sabado/. }\end{array}$ \\
\hline
\end{tabular}

17.6 Restriçăo ao hiato.

Reduzem-se os encontros silábicos $W$, quando a segunda vogal é fraca, nos seguintes casos:

/ai/ é substituido por /ay/;

/Eol por /Ew/;

$100 /$ por $/ 0 w /$.

Os vocábulos correspondentes perdem uma silaba; aumenta o número de sílabas do tipo VC, sendo a consoante um semivocóide.

Trata-se de hiatos ainda herdados do latim vulgar. Parece não ter havido nenhuma confusão, porque o nôvo ditongo /ay/ só ocorre em verbos e os demais ditongos, aparentemente, não encontraram rivais produzidos pela evolução estudada até aqui. 
Exemplos.

\begin{tabular}{|c|c|c|c|}
\hline $\begin{array}{l}\text { cantaui } \\
\text { amaui } \\
\text { deus } \\
\text { meum } \\
\text { ego } \\
\text { duos } \\
\text { suum }\end{array}$ & $\begin{array}{l}\text { "cantei" } \\
\text { "amei" } \\
\text { "deus" } \\
\text { "meu" } \\
\text { "eu" } \\
\text { "dois" } \\
\text { "seu" }\end{array}$ & $\begin{array}{l}\text {../kan'tai/ } \\
\text {../a'mai/ } \\
\text {../'dEos/ } \\
\text {../'mEo/ } \\
\text {.../'Eo/ } \\
\text {../'doos/ } \\
\text {.../'soo/ }\end{array}$ & 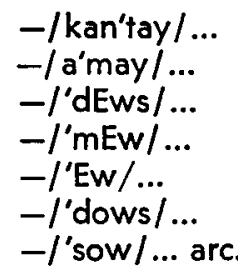 \\
\hline
\end{tabular}

\section{Evoluções silábicas.}

No terceiro estado lingǘ́stico não se criam novos tipos de sílabas nem se elimina nenhum tipo existente. Ocorrem ùnicamente restrições dos ocupantes das diversas posições na sílaba.

\subsection{Restrição à vogal /a/. \\ O ditongo /ay/ passa a /ey/.}

A vogal $/ a /$ sofre restrição diante de $|y|$ : é substituída por $\mid$ el, a não ser quando a sílaba seguinte começa por vogal. A vogal /a/ é fonema de grande abrimento bucal, que não exige apenas o afastamento da língua, mas também dos maxilares; portanto, quando segue sílaba iniciada por grande abrimento bucal, mantémse 0 abrimento $e$, por conseguinte, $0 / a /$.

\section{Exemplos.}

\begin{tabular}{|c|c|c|c|c|}
\hline $\begin{array}{l}\text { cantaui } \\
\text { amaui } \\
\text { primarium } \\
\text { ferrarium } \\
\text { operarium } \\
\text { lac } \\
\text { flagrare } \\
\text { aream } \\
\text { mataxam } \\
\text { saxum } \\
\text { fascem } \\
\text { areolam } \\
\text { basium }\end{array}$ & $\begin{array}{l}\text { "cantei" } \\
\text { "amei" } \\
\text { "primeiro" } \\
\text { "ferreiro" } \\
\text { "obreiro" } \\
\text { "leite" } \\
\text { "cheirar" } \\
\text { "eira" } \\
\text { "madeixa" } \\
\text { "seixo" } \\
\text { "feixe" } \\
\text { "eiró" } \\
\text { "beiijo" }\end{array}$ & 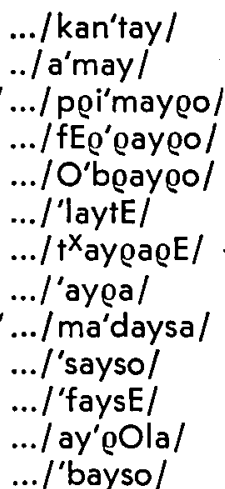 & 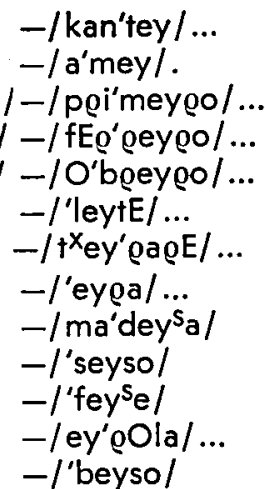 & $\begin{array}{l}=(\text { ma'deyxa)... } \\
=(\text { 'seyxo }) . . \\
=(\text { 'feyxE)... } \\
=\left({ }^{\prime} \text { beyjo } \ldots\right.\end{array}$ \\
\hline
\end{tabular}

Não evoluíram, porque o ditongo vem seguido de vogal: raio, maio, saia, etc.

Compare: (Pidal, 1930, 100): Port. Mon. 96.' Auteiro, ano de 968, (cópia do séc. XIII) (derivado de auto, êste do latim altum); 214..$^{\circ}$ : auteiru, ano 1010; 385..$^{\circ}$ leisar, leisiar, ano 1053 (do latim laxare). 


\subsection{Restriçōes semiconsoante (y).}

A tendência geral do $3 .^{\circ}$ estado lingüístico é eliminar o (y) da posição consonantal, prevocálica. São poucos os ambientes em que $\circ(y)$ ainda permanece neste ambiente, durante $03 .^{\circ}$ estado.

1. caso: Tipo de sílaba CV, depois de consoante ou em início de vocábulo.

Neste ambiente $o(y)$ é totalmente eliminado e o fone ( $d^{\prime}$ ) ocupa - seu lugar. $O(y)$ era precedido de fonema de maior cerramento bucal ou de cerramento total porque precedia o silêncio, isto é, era o início do vocábulo. Não é de estranhar que em vez de (y) se produzisse a africada correspondente.

Exemplos.

\begin{tabular}{|c|c|c|c|}
\hline $\begin{array}{l}\text { margines } \\
\text { angelum } \\
\text { longe } \\
\text { iam } \\
\text { iacere } \\
\text { iantare } \\
\text { iocum } \\
\text { iulium } \\
\text { gelat } \\
\text { gentem }\end{array}$ & $\begin{array}{l}\text { "margens" } \\
\text { "anjo" } \\
\text { "longe" } \\
\text { "iá" } \\
\text { "jazer" } \\
\text { "jantar" } \\
\text { "iôgo" } \\
\text { "iulho" } \\
\text { "geia" } \\
\text { "gente" }\end{array}$ & 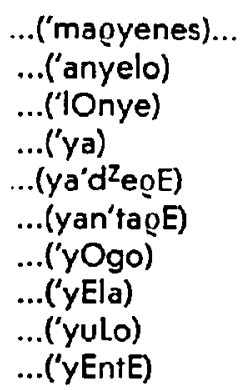 & 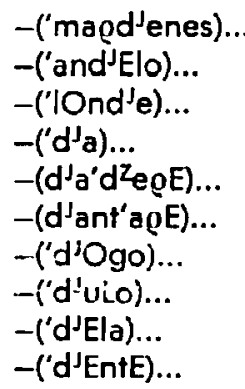 \\
\hline
\end{tabular}

2.ं caso: Tipo de sílaba CV, depois de vogal.

Neste ambiente, há três possibilidades:

a) Síncope: a semiconsoante é eliminada e, nestes vocábulos, uma sílaba do tipo CV passa a V. Entre duas vogais elimina-se 0 rápido cerramento bucal.

b) Diafonia de ( $y$ ) para (j). Como precede um fonema de grande abrimento bucal, acentua-se apenas de leve o cerramento bucal e do semivocóide palatal, sonoro surge um fricativo, palatal, sonoro o (i).

c) Muda-se o encontro silábico de V.CV para VC.V, isto é, a semiconsoante passa para a sílaba precedente. Portanto, transfonia de semiconsoante para semivogal. Não importa se houve ou não estágio intermediário: $(V . y V)-(V y . y V)-(V y . V)$; pode até o encontro silábico continuar a se realizar ( $V y . y V)$, como na atualidade se pode pronunciar meio ('mey.yU) $=/$ 'meyo/, sendo o último silabema o realizado pela silaba $(y U)$. 
As três evoluções são perfeitamente possíveis, porque em nenhum caso $O(y)$ invadiu a área de outro fone:

o fone (j) não ocorria em ambiente intervocálico, apenas depois da semivogal (y) como ('bajyo) (beijo);

o fone ( $d$ ') não existia até então;

não havia ditongos seguidos de vogal.

Trała-se, pois, de evolução silábica com implicações fônicas pela criação do fone ( $\left.d^{J}\right)$ e com implicações vocabulares com outro tipo de encontros silábicos. E se não parece possível sistematizar os fatos (quando síncope, quando diafonia, quando mudança de encontro silábico), os quais levaram a semiconsoante a evoluções diferentes, é que todos os caminhos estavam abertos, de sorte que tinham livre campo a analogia, os empréstimos do latim, de dialetos hispânicos, de outras línguas românicas. E é assim que se deve explicar a existência

a) de evoluções divergentes: radium - raio; mas medium - meo - meio; mas video - vejo; mas cuius - cujo; etc.

b) de formas esporádicas minoritárias, que não vingaram: legem - lee "lei" (cp. Nunes, 1951, 70).

"Les faits sont de plus embrouillés en portugais." (Meyer-Lübke, 1890,460 ).

\section{Exemplos.}

\begin{tabular}{|c|c|c|c|}
\hline $\begin{array}{l}\text { corrigiam } \\
\text { reginam } \\
\text { tageniam } \\
\text { rugitum } \\
\text { strigam } \\
\text { sagittam } \\
\text { sigillum } \\
\text { legere } \\
\text { saga } \\
\text { radium } \\
\text { badium } \\
\text { modium } \\
\text { medium } \\
\text { legem(1) }\end{array}$ & $\begin{array}{l}\text { "correia" } \\
\text { "rainha" } \\
\text { "tainha" } \\
\text { "ruído" } \\
\text { "estria" } \\
\text { "seta" } \\
\text { "sêlo" } \\
\text { "ler" } \\
\text { "saia" } \\
\text { "raio" } \\
\text { "baio" } \\
\text { "moio" } \\
\text { "meio" } \\
\text { "lei" }\end{array}$ & 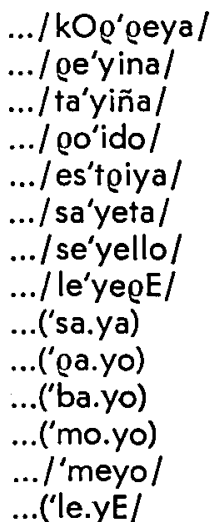 & 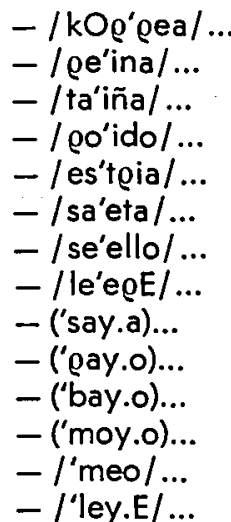 \\
\hline
\end{tabular}

(1) Embora seia atestada a forma lee "lei" (Nunes, 1951, 70), acreditamos que a evolução normal seja a que apresentamos e que leo seja forma minoritária, dialetal, porque a evoluçāo normal dos hiatos da língua galego-portuguêsa nos parece, além dos casos de conservação e de epêntese: assimilaçâo (até a crase), quando a segunda vogal é mais aberta ou de abrimento igual; oclusão (ditongaçäo), quando a segunda vogal é mais fechada. Exemplos: pode - pó; fidem - fé; molam - mó; sola - só; colorem - cốr; crudum - cru; civiles civis; sagittam - seta; soles - sóis; malum - mau; canes - cães; crudeles - cruéis; gradum - grau; vadił - vai; granum - gräo. 


$\begin{array}{llll}\text { regem } & \text { "rei" } & \text {...('ge.yE) } & - \text { ('eey.E)... } \\ \text { cuius } & \text { "cujo" } & \text {...('kuyo) } & - \text { ('kujo)... } \\ \text { hodie } & \text { "hoje" } & \text {...('oye) } & - \text { ('oje)... } \\ \text { uideam } & \text { "veja" } & \text {..('veya) } & - \text { ('veja)... } \\ \text { adiutamus } & \text { "ajudamos" } & \text {...(ayu'damos) } & - \text { (aju'damos)... } \\ \text { sedeam } & \text { "seja" } & \text {...('seya) } & - \text { ('seja)... }\end{array}$

3.ं caso: Tipo silábico CCV ou CCCV.

Neste ambiente, a última consoante representa $\circ(y)$ e ocorre evolução ùnicamente se a penúltima consoante é (i) ou (o). No tipo silábico $C C V$, o (y) passa para a sílaba precedente e o encontro silábico evolui de (V.CCV) para (VC.CV); no tipo silábico CCCV, cai o (y) e a silaba passa para CCV.

Quando ao $(y)$ precede uma outra consoante, conserva-se, como em capiat /'kabya/ "caiba"; rubeum /'govyo/ "ruivo".

Exemplos.

\begin{tabular}{|c|c|c|c|}
\hline $\begin{array}{l}\text { corium } \\
\text { materiam } \\
\text { primarium } \\
\text { ferrarium } \\
\text { operarium } \\
\text { atrium } \\
\text { basium } \\
\text { caseum }\end{array}$ & $\begin{array}{l}\text { "couro" } \\
\text { "madeira" } \\
\text { "primeiro" } \\
\text { "ferreiro" } \\
\text { "obreiro" } \\
\text { "adro" } \\
\text { "beijo" } \\
\text { "queijo" }\end{array}$ & $\begin{array}{l}\text {.../'kOoyo/ } \\
\text {../ma'dEgya/ } \\
\text {.../poi'magyo/ } \\
\text {.../fEo'gagyo/ } \\
\text {.../O'bogoyo/ } \\
\text {../'adoyo/ } \\
\text {...('bajyo) } \\
\text {...('kajyo) }\end{array}$ & $\begin{array}{l}\text { - /'kOygo/... } \\
\text { - /ma'dEyga/... } \\
\text { - /pgi'maygo/... } \\
\text { - /fE'gaygo/... } \\
\text { - /O'bgaygo/... } \\
\text { - /'adgo/... } \\
\text { - ('bayjo)... } \\
\text { - ('kayjo)... }\end{array}$ \\
\hline
\end{tabular}

18.3. Restrição ao (w), semiconsoante.

A semiconsoante $(w)$ teve evoluçäo análoga à semiconsoante $(y)$ (17.2): a mesma tendência para o desaparecimento. Como semiconsoante $O(w)$ ocorria no tipo silábico CCV.

1. caso: A 1." consoante é oclusiva ou fricativa.

$O(w)$ passa para a sílaba precedente. Isto importa na diminuição do número de silabas do tipo CCV e aumento do tipo VC, ditongo.

Exemplos.

$\begin{array}{llll}\text { sapui : sapii } & \text { "soube" } & \text {.../'sabwi/ } & - \text { /'sawbi/... } \\ \text { habuit } & \text { "houve" } & \text {.../'avwel } & - \text { /'awve/... } \\ \text { potuit } & \text { "pôde" } & \text {.../'pOdwe/ } & - \text { /'powde/... } \\ \text { posuit } & \text { "pôss" } & \text {...("pOzwe) } & - \text { ('pOwze)... }\end{array}$

Empréstimos obedeceram à mesma orientação:

\begin{tabular}{|c|c|c|c|}
\hline $\begin{array}{l}\text { aquam } \\
\text { equam }\end{array}$ & $\begin{array}{l}\text { "água" } \\
\text { "égua" }\end{array}$ & $\begin{array}{l}\text { /'agwa/ } \\
\text { /'Egwa/ }\end{array}$ & $\begin{array}{l}\text { - /'awga/... arc. } \\
\text { - /'Ewga/... arc. }\end{array}$ \\
\hline
\end{tabular}


2. ${ }^{\circ}$ caso: A $1 .^{a}$ consoante é nasal e a vogal é $/ a /$.

Epêntese de /g/ e passagem de (n) para a sílaba precedente. Mantém-se $\circ(w)$, neste ambiente, e o tipo silábico CCV.

Exemplos.

manualem(1) "mangual" minuere(2) "minguar"
.../ma'nwalE/ .../mi'nwa E/
- /man'gwalE/...

- Imin'gwa $E / . .$.

3. ${ }^{\circ}$ caso: A $1 .^{\circ}$ consoante é lateral.

O (I) passa para a sílaba precedente e é substituído por seu alofone (L); (w) é substituído por (v). Reduz-se o número de sílabas do tipo CCV; sílaba do tipo VC em que a consoante é $/ 1 /$, já existia na língua.

\section{Exemplos.}
dolverunt
"sentira dor"
"doeram"
"valesse"
.../dO'lwegon/ - /dOl'vegon/... arc.
valuisset
.../va'lwesE/
- /val'vesE/... arc.

4. ${ }^{\circ}$ caso: Tipo de sílaba CV.

(w) foi substituído por (v).

Exemplos.
credidit (creduit) "creu"
sedit (seduit) "foi"
.../'kgewe/
.../'sewe/
- /'kgeve/... arc.
- /'seve/... arc.

5. ${ }^{\circ}$ caso: Nos demais ambientes.

Aparentemente, apenas /nwE/ e /nwe/.

Conserva-se durante o terceiro estado lingüístico.

$\begin{array}{lll}\text { ianuarium } & \text { "ianeiro" } & \ldots \text { (d’a'nwey o)... } \\ \text { ianuellam } & \text { "janela" } & \ldots \text { (d'an'wElla)... } \\ \text { manuariam } & \text { "maneira" } & \ldots \text { (ma'nwey a)... }\end{array}$

\section{Evolução fônica.}

A transfonia da vibrante.

Do campo de dispersão tão amplo, por ser um fonema não-integrado, a vibrante, em certa época, se fixou na norma como apical (passando a uvular a variação livre). O fonema continua o mesmo:

(1) Numa série de vccábulos, do 2.0 e do 3.0 caso, mangual, minguar, janeiro, janela, maneira, é preciso admitir que nāo houve no latim vulgar a queda do (U), mas a sua passa. gem para $(w)$ (cf. 6.2).

(2) Em minguar, houve algum tipo de evoluçāo vocabular que permitiu a permanência de /i/ que era breve no latim vulgar. Recorde-se também que a empréstimos germânicos com (w) pode corresponder em português /gw/: wardon - guardar; werra - guerra. 
seu traço distintivo era e continua sendo o de vibrante. Mas houve transfonia: o traço irrelevante de uvular foi substituído pelo apical. Mudaram-se todos os fones do fonema. O fonema /Q/, que tinha (Q) como alofone, passa a ter agora como alofone (R) em todos os ambientes. Como (o) não existe mais, a não ser como realização no idioleto, convém representar o fonema pela lêtra $R$ : / R/. Fonema / $/$ com alofone ( $R$ ). Não haveria problema, se alguém mantivesse a lêtra $\mathrm{Q}$ : Fonema $/ \mathrm{Q} / \mathrm{com}$ alofone $(R)$. O fonema continua como vibrante; mudou o alofone de (o) uvular, vibrante, sonora para (R) apical, vibrante, sonora. Não se alterou o fonema, o valor; alterou-se o alofone.

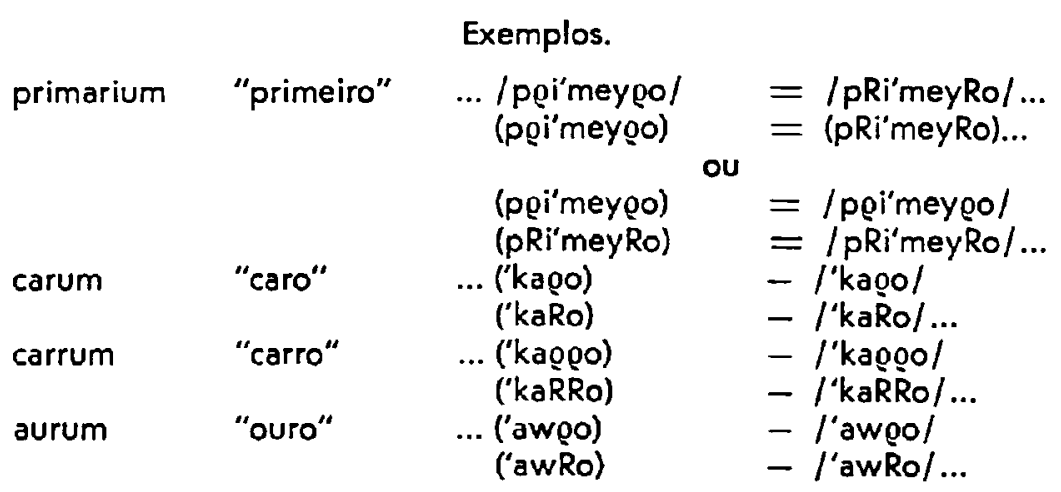

\section{Evoluçōes fonêmicas.}

Evolução vocabular (17.2; 17.4; 17.5) e evolução silábica (18.2) desencadearam mudanças no esquema fonêmico e prepararam o advento do $4 .^{\circ}$ estado linguístico com nôvo sistema de consoantes.

\subsection{A fonemia do $/ \mathrm{d}^{2} /$.}

Pela sonorização das consoantes surdas (17.2), o fonema $/ 1^{s} /$ obteve o alofone $\left(d^{2}\right) .\left(d^{2}\right)$ ocorria ùnicamente entre vogais e $\left(t^{5}\right)$, nos demais ambientes. Entretanto, pela síncope de consoantes implosivas diante de consoantes africadas (17.4), a alofone surdo $\left(t^{5}\right)$ também se encontra em ambiente intervocálico: automàticamente o fone ( $d^{2}$ ) entra em oposição ao $\left(t^{5}\right)$ e sofre fonemia para $/ d^{2} /$, com os traços distintivos de africado e sonoro; o fonema $/ t^{5} /$ passa por transfonemia, uma vez que adquire o traço distintivo de surdo. $\mid t^{s} /$ e $/ d^{2} \mid$ se comprovam como fonemas diferentes, por estarem no mesmo ambiente - intervocálico -, e pelos ambientes análogos caça, coza e faze, do latim captiat, cocat (em vez do latim clássico coquat) e facet (em vez de facit): /'katsa/, /'kOdza/ e /'fad'z/.

O fonema / $d^{2} /$ tinha dois alofones: $\left(d^{2}\right)$ e $\left(d^{J}\right)$, o último oriundo 
da evolução do (y) (18.2). Comprovam-se como um só fonema, porque ocorrem em ambientes diferentes: ( $d$ ') só depois de consoante e em início de vocábulo;

$\left(d^{2}\right)$ só entre vogais.

Escolhemos $\left(d^{Z}\right)$ como representante, embora $\left(d^{J}\right)$ possa parecer mais versátil, ocorrer em mais ambientes. E que històricamente, o fone apical precede $\circ$ frontal: $\left(t^{S}\right)$ existiu antes de $\left(t^{x}\right) ;(s)$ antes de $(x) ;(n)$ antes de $(\tilde{n}) ;(I)$ antes de $(L)$ O segundo motivo é a simetria: o apical fricativo é o fonema /s/ e (x) seu alofone.

O fone $\left(d^{J}\right)$ não pode ser considerado como alofone de $/ \dagger^{x} /$, porque ocorrem no mesmo ambiente: em início de vocábulo e depois de consoante $(14.3 ; 18.2)$. Ambientes análogos: já e chave do latim iam e clauem; longe e enche do latim longe e implet. (' $\left.d^{\jmath} a\right):\left({ }^{\prime} t^{\prime} a-\right.$ $v E) ;\left(\right.$ 'IOnd'e) : ('ent $\left.{ }^{\mathrm{X}} \mathrm{E}\right)$.

\section{Exemplos.}

\begin{tabular}{|c|c|c|c|}
\hline rationem & "razão" & $\begin{array}{l}\text { (Ra'tsonE) } \\
\text { (Ra'd }{ }^{z} \text { OnE) } \\
\text { (Ra'd }{ }^{\prime} \text { onE) }\end{array}$ & $\begin{array}{l}=/ R a^{\prime}+t_{\text {SonE }} / \\
=/ \mathrm{Ra}^{\prime}+S_{\text {SonE }} / \\
=/ \mathrm{Ra}^{\prime} \mathrm{d}^{2} \text { onE } / . . .\end{array}$ \\
\hline dicit & "diz" & $\begin{array}{l}\text { ('dit'sE) } \\
\text { ('didze) }\end{array}$ & $\begin{array}{l}=/ \operatorname{dit}^{\mathrm{S}} \mathrm{E} / \\
=/ \mathrm{dit}^{\mathrm{S}} \mathrm{E} /\end{array}$ \\
\hline luces & "luzes" & $\begin{array}{l}\text { ('didze) } \\
\left.\text { ('lut }{ }^{S} e s\right) \\
\text { ('ludzes) } \\
\left.\text { ('lud } d^{Z} e s\right)\end{array}$ & 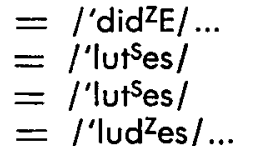 \\
\hline iam & "já" & $\begin{array}{l}\text { ('ya) } \\
\text { ('d'a) }\end{array}$ & $\begin{array}{l}=/ \text { yal } \\
=/ \mathrm{dz}^{\prime} \mathrm{a} / \ldots\end{array}$ \\
\hline iocum & "jôgo" & ('yOgo) & $=$ I'yOkol \\
\hline longe & "longe" & $\begin{array}{l}\text { ('IOnye) } \\
\text { ('IOond'e) }\end{array}$ & $\begin{array}{l}=/ \text { 'lonyel } \\
=/ \text { 'lond'e/... }\end{array}$ \\
\hline
\end{tabular}

\subsection{A fonemia de $/ z /$.}

O fonema / s / tinha dois alofones: $(x)$ entre um (y) e uma vogal; entre uma vogal e um (y); (s) nos demais ambientes. (13.2).

A sonorização das consoantes surdas (17.1) trouxe quatro fones fricativos:

(x) entre um (y) e uma vogal, (pois não se sonorizou);

(z) entre vogais e entre (w) e uma vogal;

(j) entre uma vogal e um (y);

(s) nos demais ambientes. 
Como os quatro ocorrem em ambientes diferentes, são todos alofones do mesmo fonema fricativo $/ \mathrm{s} /$.

Pela simplificaçāo das geminadas (17.5), ressurge o fone (s) em posição intervocálica. A partir dêste momento, os fones (s) e (z) estão em oposição e passam a constituir dois fonemas diferentes $/ \mathrm{s} /$ $e|z|$. Os fones $(x)$ e (j) não estão em oposição entre si; também não há oposição entre (s) e (x); nem entre (z) e (i). A solução é considerar o fonema / $\mathrm{s} / \mathrm{com}$ dois alofones:

(x) entre (y) e uma vogal;

(s) nos demais ambientes.

$|z|$ com dois alofones:

(i) entre uma vogal e (y);

(z) nos demais ambientes.

Fala a favor desta solução:

a) São alofones os sons mais semelhantes entre si: um fonema compreende dois fones surdos; o outro, dois fones sonoros.

b) A simetria: O fonema $\left(d^{2}\right)$ tem dois alofones, um apical $\left(d^{2}\right)$ e outro frontal $\left(d^{\prime}\right)$; continuam, entre os fricativos também, como alofones entre si o apical e o frontal.

c) Pela transposição de (iy) para (yi) (18.2), entram em oposição os fones $(x)$ e (j). parque ambos ocorrem entre um $(y)$ e uma vogal. Esta evolução nos obriga considerá-los como pertencentes a fonemas diferentes.

A fonemia de $\mid z /$, com os traços distintivos de não-labial, fricativo sonoro, causou a transfonemia de $/ \mathrm{s} /$, porque se the incorporou - traço distintivo de surdo. O par minimo cassa do latim cassat e casa do lat. casam prova a existência dos dois fonemas: /'kasa/ : /'kaza/.

Exemplos.

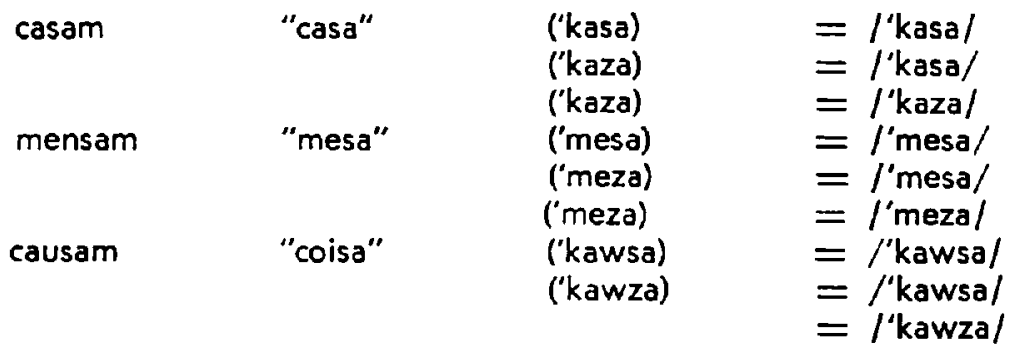




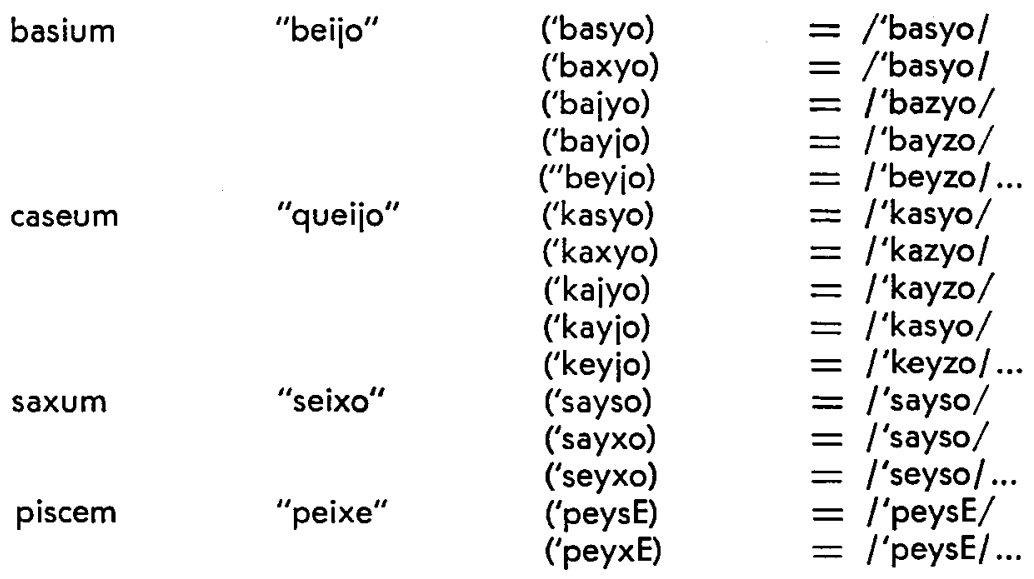

\subsection{A fonemia de /i/.}

A sonorização trouxe o fone (i), que era de reduzida distribuição - ocorre apenas depois de um (y). A evolução silábica, que luta contra os grupos de consoantes e contra a presença de semivocóide em início de sílaba, encontrou um excelente campo aberto para vencer e descartar-se do (y) em início de sílaba: substitui o (y) por (j), sem causar confusão entre os vocábulos, porque

(j) oriundo de ( $x$ ) está entre um (y) e uma vogal;

(i) oriundo de (y) está entre vogais. (18.2)

A evolução silábica traz a mudança dos vocábulos atingidos e causa evolução fonêmica, pois nos obriga a uma nova interpretação: 0 fonema $|z|$ cinde-se em dois fonemas $|z|$ e $\mid i /$.

Entraram em oposição os fones (j) e (z):

(z) oriundo da sonorização de (s) (17.2 e 20.2) ocorre entre vogais e entre $(w)$ e uma vogal;

(j) oriundo de (sy) - (xy) - (iy) (13.2, 17.2 e 18.2) ocorre entre $(y)$ e uma vogal;

oriundo de $(y)(18.2)$ ocorre entre vogais.

(j) entra em oposição ao (z) entre vogais e alcança a sua inde. pendência como fonema $/ \mathrm{i} /$ : fonemia de $/ \mathrm{j} /$ com os traços distintivos de posterior, fricativo sonoro e transfonemia de $|z|$, que passa de não-labial, fricativo, sonoro para apical, fricativo, sonoro.

O fonema /i/ ocorre em dois ambientes:

entre vogais, onde forma oposição ao $|z|$; e 
entre (y) e uma vogal, onde forma oposição ao (x), alofone de /s/ $(20.2)$.

Mas (i) não está em oposição ao ( $\left.d^{\jmath}\right)$ :

(d) ocorre em início de vocábulo e depois de não-vocóide (18.2);

(j) ocorre entre vogais e depois de semivocóide (y).

Não é possivel considerá-los como alofones entre si, por três razōes:

a) O comportamento dos fonemas: $/ z /$ e $/ d^{z} /$ se mantêm distintos porque ambos ocorrem entre vogais (7.2)i $/ \mathrm{s} / \mathrm{e} / \mathrm{t}^{\mathrm{s}} /$ estão em opo. sição em início e no interior do vocábulo (9.2 e 17.4). Se os africados, na ordem dos apicais, são fonemas diferentes dos fricativos, deve manter-se coerência e manter solução idêntica na ordem dos fonemas posteriores, embora não estejam em oposição nem os fones (j) e $\left(d^{j}\right)$ e nem os fones $(x)$ e $\left(t^{x}\right)$.

b) A simetria no diagramema: os fricativos surdos, apical (s) e fronral $(x)$ são alofones entre si. Convém manter a mesma solução para cs africados: apical sonoro e frontal sonoro, $\left(d^{2}\right)$ e ( $\left.d^{J}\right)$, também são oposição ao $/ t^{x} /$.

c) Quando surge o fonema $|x|$ no $4 .^{\circ}$ estado lingüistico, éle está em oposiçāo ao $/ \uparrow^{x} /$.

Em todo caso, entre as consoantes posteriores sonoras, a africada (d') e a fricativa /i/, está a brecha no sistema, por onde as africadas começarão a se precipitar nas fricativas correspondentes. (25.3.) A solução proposta nos parece melhor não só pelas três razões já expostas, como também por outro fato: a língua, provàvelmente, já contava com o fonema / $/$ / em início de vocábulo, como também $0 / x /$, por causa de empréstimos árabes. Já que existiam os alofones $(j)$ e $(x)$ em inicio de silaba, a língua não teria resistência contra empréstimos que os tivessem numa distribuição tão fácil como o início de vocábulo, sobretudo porque todos os traços fônicos já eram distintivos. Tais empréstimos teriam colocado imediatamente em oposiçāo e como fonemas $|i|$ e $\mid d^{J} /$, além de $|x|$ e $\left(t^{x}\right)$. E uma hipótese que merece pesquisa. Não procuramos resolvê-la, porque aqui tratamos da evolução do sistema fonêmico do latim para o português.

Exemplos.

cuius

adiutare

hodie

uideam

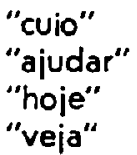

"veja"

$$
\begin{array}{ll}
\text {.../kuyo/ } & =\text { /'kujo/... } \\
\text {../ayu'daRE/ } & - \text { /aju'daRE/... } \\
\text {../'oye/ } & - \text { /'oie/. } \\
\text {.../'veya/ } & \text { - /'veja/. }
\end{array}
$$




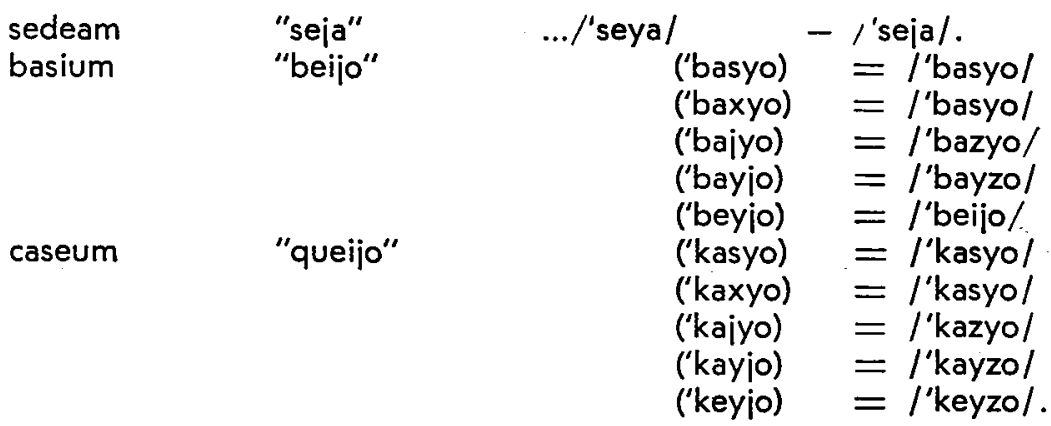

\section{Os fonemas do galego-português.}

As evoluções que se processaram no terceiro estado lingüístico, trouxeram um nôvo sistema de consoantes. O resultado é o quarto estado lingüístico, uma nova língua, que denominamos galégo-portuguêsa. Preferimos a expressão língua galego-portuguêsa e não português arcaico, como distinto do galego arcaico, porque istó nos levaria a um contrassenso: D. Dinis, que era português, teria empregado galeguismos e Ayras Nunes, que era galego, não apresenta galeguismos (cf. Mattos, 1962. 3.3.1). A língua era uma só; as divergências eram variantes livres.

E de se notar que o sistema de vogais continua inalterado.

O sistema de consoantes.

21.1. O diagramema das consoantes.

\begin{tabular}{|c|c|c|c|c|}
\hline & & LABIAIS & APICAIS & POSTERIORES \\
\hline \multirow{2}{*}{ OCLUSIVAS } & \multirow{2}{*}{$\begin{array}{l}\text { surdas } \\
\text { sonoras }\end{array}$} & $/ p$ & $t$ & $k$ \\
\hline & & $b$ & $d$ & $g$ \\
\hline \multirow{2}{*}{ AFRICADAS } & surdas & & $t^{5}$ & $t^{x}$ \\
\hline & sonoras & \multicolumn{3}{|c|}{$d^{z}$} \\
\hline \multirow{2}{*}{ FRICATIVAS } & surdas & $f$ & \multicolumn{2}{|c|}{$\mathbf{s}$} \\
\hline & sonoras & $v$ & $z$ & $\mathrm{i}$ \\
\hline NASAIS & & $\mathrm{m}$ & $n$ & $\tilde{n}$ \\
\hline LATERAIS & & \multicolumn{3}{|c|}{1} \\
\hline VIBRANTE & & \multicolumn{3}{|c|}{$\mathrm{R}$} \\
\hline SEMIVOCOIDES & & $w$ & & 1 \\
\hline
\end{tabular}


21.2. O diagrama das consoantes.

LABIAIS

Bilab.Labiod. Apicais Frontais Velares

\begin{tabular}{|c|c|c|c|c|c|c|}
\hline \multirow{2}{*}{ OCLUSIVAS } & surdas & (p & & $t$ & & k \\
\hline & sonoras & $b$ & & $d$ & & $\mathbf{g}$ \\
\hline \multirow{2}{*}{ AFRICADAS } & surdas & & & $t^{s}$ & $t^{x}$ & \\
\hline & sonoras & & & $d^{2}$ & $d^{J}$ & \\
\hline \multirow{2}{*}{ FRICATIVAS } & surdas & & $f$ & $\mathbf{s}$ & $x$ & \\
\hline & sonora & & $v$ & $z$ & i & \\
\hline NASAIS & sonoras & $\mathrm{m}$ & & $n$ & $\tilde{\mathbf{n}}$ & \\
\hline LATERAIS & sonoras & & & $1 \lambda$ & $\mathbf{L}$ & \\
\hline VIBRANTE & sonoras & & & $\mathbf{R}$ & & \\
\hline SEMIVOCOIDES & sonoras & $w$ & & & y) & \\
\hline
\end{tabular}

- fonema $\left(d^{2}\right)$ tinha dois alofones: $\left(d^{J}\right)$ em inicio de sillaba, precedido de consoante ou de pausa (= inicio de vocábulo); $\left(\mathrm{d}^{\mathrm{Z}}\right)$ nos demais ambientes.

/s/ tinha dois: $(x)$ entre $(y)$ e uma vogal; (s) nos demais ambien. tes.

II/ tinha dois: ( $\lambda$ ) depois de vogal; (I) antes de vogal. 